\title{
Performance e análise da sonoridade em Contrastes de Marisa Rezende
}

\author{
Performance and analysis of the sonority in "Contrastes" by Marisa \\ Rezende
}

\author{
Bibiana Bragagnolo \\ Didier Guigue
}

Universidade Federal da Paraíba

\begin{abstract}
Resumo: Este artigo tem como principal objetivo apresentar uma análise da sonoridade na peça Contrastes, da compositora Marisa Rezende, onde elementos advindos da performance e da partitura são analisados lado a lado como fonte de informações sobre a construção da sonoridade na peça. Para realizar tal objetivo, utilizamos a metodologia de análise da sonoridade de Guigue, aliada à análise com suporte computacional, utilizando os softwares Open Music e Sonic Visualiser, e também os pressupostos investigativos da Pesquisa Artística. Tendo como base que o elemento central da sonoridade nesta peça são os contrastes, estes foram analisados através da metodologia acima explicitada utilizando arquivos de MIDI e áudio com as gravações da peça. Desta maneira, este artigo apresenta uma metodologia analítica que tornou possível perceber e explicitar a influência da performance na construção da sonoridade de Contrastes.
\end{abstract}

Palavras-chave: Análise da sonoridade; Pesquisa artística; Marisa Rezende; Performance; Música para piano.

Abstract: The aim of this paper is to present an analysis of the sonority in the piece Contrastes, by Marisa Rezende, in which elements from the performance and from the score are analyzed side by side as important sources of information about the construction of the piece's sonority. To achieve this aim, the methodology of sonority analysis by Didier Guigue was applied ("Estética da sonoridade", 2011) in combination with the approach of artistic research and using computational support from the software "Open Music" and "Sonic Visualiser". Understanding that contrasts are the main characteristic of the sonority in this piece, they were analyzed using the methodology mentioned before that also included MIDI and audio files with recordings of the piece. The analytical methodology made it possible to perceive and explain the influence of the performance in the construction of the sonority of Contrastes.

Keywords: Analysis of the sonority; Artistic research; Marisa Rezende; Performance; Piano music. 


\section{Introdução}

Neste artigo será apresentada uma análise da sonoridade da peça Contrastes (2001), para piano solo, da compositora Marisa Rezende. A concepção aqui adotada é a de que a sonoridade global de qualquer peça é o resultado da somatória das contribuições de compositor e intérprete: de um lado o compositor estabelece elementos invariáveis, como altura, registro, textura, entre outros, e do outro lado o performer inclui com sua abordagem instrumental a realização efetiva dos intentos do compositor, além de adicionar elementos pessoais e intrínsecos à performance através de suas decisões interpretativas, que, sendo pessoais de cada intérprete, podendo variar entre diferentes performers, constituem as variáveis da obra.

Este posicionamento subentende uma mudança na visão da obra musical, que não mais é percebida como objeto idealizado, e passa de um entendimento ontológico para um entendimento morfológico (Costa 2016). Se, por um lado a ontologia "versaria sobre as condições que devem ser satisfeitas para que haja obra", a pergunta da morfologia "versa sobre o aspecto perceptual da música e as transformações sofridas de performance a performance e a maneira como essas transformações ocorrem" (Caron 2011, p. 2). Desta maneira, pode-se concluir que enquanto a primeira é uma investigação "eminentemente teórica", a segunda seria "um mergulho nas contingências de performance que caracterizam nosso mundo musical" (Caron 2011, p. 79). Em outras palavras, passa-se de um entendimento da obra musical enquanto objeto ideal representado pela partitura e parte-se para o entendimento da mesma enquanto acontecimento.

Dentro desta premissa, o performer se torna elemento central no processo analítico, de modo que não mais é possível dissociar performance e análise. Para o estabelecimento de uma metodologia analítica capaz de abarcar os dois aspectos da sonoridade na peça selecionada, nesta pesquisa performer e analista se encontrarão na mesma pessoa, ou seja, a pianista, primeira autora, atuará como performer, interpretando a peça e executando-a, e também atuará como analista juntamente com o segundo autor, no processo de coleta e análise de dados. Este duplo papel se ancora nos paradigmas da Pesquisa Artística (Coessens et al. 2009). Neste gênero de pesquisa o artista, seja ele compositor ou performer (no caso da música), atua como pesquisador, no sentido tradicional da palavra, sem abrir mão de seu papel de artista. Os problemas estéticos têm sido tratados na pesquisa de um ponto de vista filosófico, contextual ou histórico/ analítico, 
criando novas teorias e explicações. Porém, nenhuma dessas disciplinas olhou a arte a partir do ponto de vista da prática artística - a visão de dentro do processo (Coessens et al. 2009, p. 44). Assim, a pesquisa artística vem auxiliar metodologicamente no processo de inserção da voz do artista nos processos reflexivos e no contexto da pesquisa em arte.

Entendido o conceito primordial desta análise, que busca a inserção da performance dentro do contexto analítico, ancorada pelos conceitos da Pesquisa Artística, o procedimento analítico foi desenvolvido tendo como base a metodologia de análise da sonoridade estabelecida por Guigue (2011). Porém, foi inserido ao procedimento o contato experiencial com a peça como fonte de informação sobre a sonoridade, o que se deu através da atuação da performer no processo, tanto nas gravações da peça em áudio e MIDI, quanto na análise destes dados. Para tal análise foram utilizados suportes computacionais, sendo eles os softwares Open Music e Sonic Visualiser.

Esta pesquisa se insere dentro de uma pesquisa de Doutorado de maior escopo, que intenciona investigar e testar metodologias de análise da sonoridade experimentais, tendo como foco a percepção de música como acontecimento, do qual a performance não pode ser desvinculada.

\section{Construção da sonoridade na performance de Contrastes de Marisa Rezende}

A peça Contrastes (2001) da compositora Marisa Rezende, tem como principal elemento da sonoridade, tanto em sua escrita quanto em sua performance, os contrastes sonoros, como o próprio título já traduz. Os contrastes na escrita da peça são explorados essencialmente em quatro elementos principais: dinâmica, articulação, registro e textura. Desses quatro elementos, registro e textura nunca são explorados isoladamente, mas sempre acompanhados de alterações na dinâmica e/ou na articulação, o que indica a relevância destes últimos dois aspectos.

Rezende, ao falar sobre a peça, afirma que em Contrastes se "parte do princípio que a mesma coisa pode ter muitas faces e suscitar vários olhares" (Rezende 2012, encarte do CD Piano Presente). Isso leva ao entendimento de que os contrastes são percebidos como maneiras diferentes de se observar um mesmo elemento sonoro. Partindo da ideia dos vários olhares, entende-se que, além do próprio olhar da compositora, já registrado na escrita da peça, o olhar do 
performer vem também acrescentar nas possibilidades de visualização dos elementos sonoros apresentados, somando novos contrastes além daqueles já explicitados.

Assim, visando um olhar ampliado sobre as muitas faces dos elementos sonoros, a construção da sonoridade nesta performance de Contrastes partiu do princípio de que, enquanto registro e textura aparecem na peça como elementos pré-determinados, onde não foi realizada nenhuma alteração por parte da intérprete, a articulação e as dinâmicas aparecem como a porta de entrada para que o olhar de fora seja incluído na compreensão e criação dos contrastes sonoros, acrescentando novas facetas àquelas já propostas pela compositora.

A concepção dos contrastes se deu em dois níveis na peça, que se relacionam diretamente com a sua forma. Primeiramente, existem unidades maiores, que podem ser identificadas como frases musicais, que contrastam entre si, principalmente no que diz respeito ao seu caráter. Neste nível macro, as mudanças de registro, textura e manipulação temporal atuam de maneira decisiva na geração de contraste. Entretanto, ao observar o comportamento da sonoridade no interior de cada uma destas frases, é possível verificar que há também contrastes internos, principalmente em termos de articulação e dinâmica. Entendido este duplo aspecto dos contrastes, pode-se dizer que a peça se compõe por frases sucessivas, que contrastam entre si e, internamente, estas frases comportam contrastes entre seus elementos constituintes.

Enquanto o nível macro dos contrastes se relaciona com as decisões da compositora, o nível interno dos mesmos se relaciona mais diretamente com as escolhas do performer. Assim, a premissa é de que enquanto os contrastes internos são o ponto de abertura da obra, onde há possibilidade de variação, os contrastes entre frases são o que constitui o principal elemento de garantia de invariância na sonoridade da peça.

Uma vez que mudanças de registro e textura estão sempre acompanhadas de mudanças na articulação e/ ou dinâmicas, tomar-se-á estes dois últimos elementos como aqueles considerados intrínsecos na constituição sonora da peça. Além de atuarem como fatores decisivos na criação dos contrastes, estes elementos estabelecem a conexão inerente entre compositora e intérprete: as articulações e dinâmicas estão grafadas na partitura (pelo menos de maneira global), porém a sua realização efetiva dependerá da abordagem do intérprete no instrumento. Indo além, e entendendo que a partitura não é capaz de 
MUSICA THEORICA Revista da Associação Brasileira de Teoria e Análise Musical 2018, v. 3, n. 2, p. 1-45 - Journal of the Brazilian Society for Music Theory and Analysis @ TeMA 2018 - ISSN 2525-5541

comportar indicações a respeito de tudo, elementos de contraste de dinâmicas e articulação serão englobados na performance a partir de decisões interpretativas.

\section{Os elementos centrais da sonoridade na performance de Contrastes}

Como já mencionado anteriormente, dois elementos são mais relevantes nos contrastes internos de Contrastes, sendo eles a dinâmica e a articulação. Sobre a dinâmica no piano, sabe-se que ela está estreitamente relacionada com a velocidade de ataque do martelo na corda. "Um toque $p p$ imprime uma energia de aproximadamente $7 \mathrm{~mJ}$ no toque e o percurso dura $83 \mathrm{~ms}$. Para um toque $\mathrm{fff}$, os valores obtidos foram de 290mJ e 17ms20" (Lieber 1985 apud Guigue et al. 2014, p. 146). Estes valores sofrem algumas alterações conforme o registro utilizado, porém sempre mantendo a relação de uma energia menor para um som $p p$ e uma energia maior para um som fff. Esses dados demonstram que a diferença dinâmica no piano é obtida através da velocidade de ataque (quanto mais rápida, mais intenso o som e vice-versa) e também com a força deste ataque (quanto mais forte o ataque, mais intenso o som e vice-versa). Também relevante é que além da intensidade do som, as mudanças dinâmicas no piano ocasionam também mudanças de timbre, numa relação onde "a complexidade do espectro é linearmente função da intensidade" (Guigue et al. 2014, p. 147).

Sobre o segundo elemento, a articulação, entende-se que no piano ele é a resultante da variação e combinação de três elementos: velocidade de ataque, duração da nota e uso dos pedais. A conjunção destes três elementos gera tipos de toque específicos, como legato, non legato e staccato. Variando e combinando os três elementos, é possível obter incontáveis tipos de toque no instrumento além dos três citados como exemplo. A combinação destes diferentes toques é o que gera a articulação.

Considerando os dois elementos manipuláveis pelo performer utilizados para definir os elementos contrastantes na peça (dinâmica e tipo de toque), entende-se que existem três fatores de execução pianística relevantes para sua realização, sendo eles: velocidade de ataque na tecla, duração da nota (o que inclui o tempo de manutenção da tecla abaixada) e o uso dos pedais (neste caso dos pedais una corda e do pedal da direita). 
Através destes elementos listados pode-se manipular o timbre no que concerne os seguintes elementos constituintes do timbre no piano (Guigue et al. 2014, p. 153):

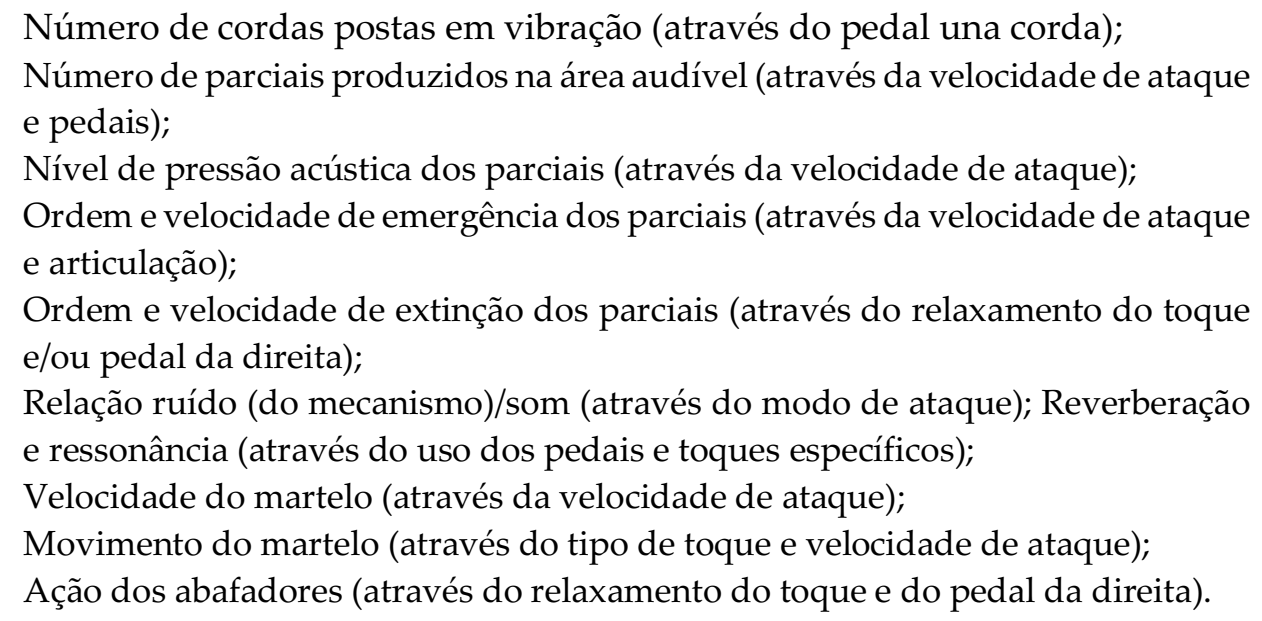

Deste modo, confirma-se que através destes elementos manipuláveis na criação de contraste sonoro na peça, tem-se possibilidade de interferir no timbre global do piano de maneira consistente, atuando na maior parte dos elementos constituintes do timbre no instrumento.

\section{Metodologia de análise}

Identificados os elementos centrais que compõem a sonoridade em Contrastes, buscou-se uma metodologia analítica que fosse capaz de incluir o entendimento acerca do comportamento destes elementos. Uma vez que os contrastes internos ocorrem a partir da combinação de alterações na dinâmica, no tipo de toque, no registro ou na textura, compreendendo que mudanças de textura e registro sempre acarretam mudanças de dinâmica e articulação, esta análise da sonoridade focará, sobretudo, na observação dos contrastes sonoros em termos de (1) velocidade de ataque, (2) uso dos pedais e (3) duração das notas (tempo que a tecla permaneceu abaixada), sendo que textura e registro serão analisados em paralelo a estes três elementos principais.

Além dos contrastes claramente perceptíveis através da leitura da partitura, foram inseridos alguns elementos de contraste a partir de indícios apresentados pela compositora. Por exemplo, no compasso 21, há uma alteração na textura e no registro, que já indica um contraste com os compassos precedentes. Assim, a fim de salientar a mudança, houve a decisão interpretativa 
MUSICA THEORICA Revista da Associação Brasileira de Teoria e Análise Musical 2018, v. 3, n. 2, p. 1-45 - Journal of the Brazilian Society for Music Theory and Analysis @ TeMA 2018 - ISSN 2525-5541

de realizar uma alteração no toque e na dinâmica neste compasso. Da mesma maneira, em outros momentos da peça a escrita foi o motor para inclusão de novos elementos geradores de contraste.

Para fins conceituais, a análise da sonoridade nesta peça se fundamentará no conceito de sintagma formulado por Guigue (2011):

Sintagma é um conjunto sequencial binário de unidades [sonoras], sendo que uma é determinante e outra, determinada. É por reação ao elemento determinante que o determinado se define, seja como sua "resposta", seja como sua "consequência", seja ainda como seu "complemento". Por exemplo, uma sonoridade composta de gestos de tipo melódico, em "resposta" a um determinante composto de blocos sonoros compactos (2011, p. 75).

Assim, entende-se que cada frase é formada por um sintagma, ou em outras palavras, por dois elementos sonoros contrastantes em alguma esfera de sua configuração. Nesta análise o conceito de sintagma será ampliado, podendo existir em cada frase mais de duas unidades contrastantes; o sintagma aqui não mais é binário, mas entendido como formado por unidades contrastantes, ainda mantendo a relação de determinante e determinado. Dentro desta concepção é importante ressaltar que "não se deve pensar que o enunciado de um determinante é, por si só, capaz de gerar uma dinâmica de expectativa, de necessidade, quanto ao aparecimento subsequente de um determinado: a estrutura interna binária do sintagma, em si, não é morfológica" (Guigue 2011, p. 75). A aparição de um determinante não gera expectativa em relação ao surgimento de um determinado; apesar da relação de reação entre um e outro, eles não necessariamente têm um aspecto auditivo de causa e consequência.

$\mathrm{Na}$ análise dos sintagmas em Contrastes, será possível observar que em determinados momentos a unidade se fecha com a apresentação do determinante e determinado, e por vezes há um retorno do determinante, gerando uma configuração determinante - determinado - determinante. Esse aspecto de retorno às características sonoras do determinante salientam as diferenciações entre um e outro. Cada sintagma nesta análise corresponderá a uma frase musical, de modo que as menções às frases correspondem às menções aos sintagmas. Sobre a delimitação dos sintagmas, faz-se necessário salientar que estas foram realizadas tendo como base primordial a experiência prática com a peça e as decisões interpretativas. A partitura aparece nesse processo como um 
elemento já filtrado pela visão do performer, de maneira a não figurar enquanto elemento abstrato, mas sempre contextualizada dentro na performance.

A metodologia analítica se dará com base na análise de dados de MIDI e áudio referentes à performance da peça realizada pela pianista e primeira autora desta pesquisa. Os dados MIDI foram gerados a partir de um piano digital Clavinova CVP-70, enquanto os dados de áudio foram captados com uma câmera Sony HDR-MV1. Dentre inúmeras gravações, foi selecionada para análise aquela que mais correspondeu às decisões interpretativas pré-formuladas. Dos dados coletados, informações foram extraídas utilizando os softwares Sonic Visualiser e Open Music, sendo que com o primeiro deles foram realizadas as análises do áudio e com o segundo as análises dos arquivos MIDI.

Uma vez que em Contrastes os elementos principais da sonoridade detectados nesta interpretação da peça foram dinâmica, tipo de toque (articulação) e uso dos pedais, optou-se por analisar nos arquivos MIDI os elementos: (1) velocity (que corresponde à velocidade de ataque na tecla e se reporta diretamente à dinâmica e tipo de toque); (2) uso dos pedais una corda e pedal da direita, que foram os pedais utilizados nesta interpretação da peça e; (3) duração das notas, que corresponde ao tempo que a tecla se manteve pressionada. Estes três elementos combinados geram tanto a dinâmica quanto os diversos tipos de toques, que combinados criam a articulação. A análise de cada um deles se deu de acordo com a utilização dos mesmos em cada frase; em algumas delas somente o pedal atuou como elemento de contraste, enquanto em outras os três elementos atuaram em simultaneidade. Por isso, a análise de cada frase corresponde à sua formação sonora, diferenciando-se de uma para outra.

O software Open Music foi utilizado para extrair as informações acima descritas, sendo utilizados os seguintes dados: (1) velocity, que dá um valor de 0 a 127 para a velocidade de ataque de cada nota, sendo 0 o mínimo de velocidade e 127 o máximo; (2) a duração das notas em onsets, que representa o tempo real de duração das notas, ou seja, o tempo que a tecla permaneceu abaixada: e (3) qualidade sônica básica (Q). Este último parâmetro é resultado de um cálculo que define um valor de 0 a 1 para cada nota em termos de sua qualidade tímbrica. $O$ valor de $\mathrm{Q}$ depende fundamentalmente de três parâmetros: (1) as alturas absolutas (MIDI notes) contidas na unidade, (2) sua intensidade relativa (MIDI velocities) e (3) uso dos pedais da direita e una corda (Guigue 2016, p. 15). O cálculo de $Q$ leva em consideração a complexidade tímbrica relativa do objeto pianístico 
a partir do princípio geral de um declínio na complexidade tímbrica de cada nota em proporção à altura da sua frequência fundamental, de modo que quanto mais aguda esta, menos complexa é sua qualidade espectral. Os três fatores acústicos deste declínio são: (1) o decréscimo do número de parciais audíveis para a fundamental dada, (2) o decréscimo da posição, no espectro, do ou dos parciais mais fortes ${ }^{1}$ e (3) a diminuição da duração da fase de extinção do som (Guigue 2016: 15). A combinação destes três valores produz o fator $Q$, que aplica um peso para cada nota em termos de sua qualidade sônica intrínseca.

Nos arquivos de áudio a análise foi realizada através do software Sonic Visualiser e contou com dois parâmetros: centroide espectral (CE) e espectrograma. O centroide espectral traz informações sobre o timbre, mostrando onde se encontra o centro de massa de determinado espectro sonoro, além de se relacionar diretamente com o brilho, de modo que quanto mais alto o valor do centroide, mais brilhante é o som e quanto mais baixo o valor, mais opaco (LOUREIRO et al. 2008, p. 119). Já o espectrograma traz informações sobre a localização dos harmônicos presentes no espectro de cada nota, e suas intensidades, de modo que se pode obter uma visão geral da constituição do som nota a nota.

A análise da sonoridade em Contrastes será exposta a partir da divisão fraseológica da peça, que será apresentada no tópico seguinte.

\section{Forma e decisões interpretativas}

A forma de Contrastes se relaciona diretamente com o entendimento interpretativo da peça. Em outras palavras, a forma não aparece como um dado pré-definido, mas sim como um elemento que é moldado a partir do processo performático e das decisões interpretativas, sendo que a observação e apropriação do texto por parte do intérprete definirá a forma.

De maneira global, Contrastes se divide em duas grandes partes: A, que vai do início até o compasso 34, e B, que vai do compasso 35 ("Mais calmo") até o final da obra. A segmentação em duas partes se dá principalmente pela rarefação rítmica que ocorre no fim da seção A, a partir do compasso 27, que culmina com

\footnotetext{
${ }^{1}$ Com efeito, uma fundamental grave gera um espectro onde ela não aparece como parcial proeminente, fenômeno que vai desaparecendo à medida que ela sobe, para, nos registros de médio para agudo, ambos se confundirem na mesma nota.
} 
acordes longos com fermata no compasso 32. Os compassos 33-34 são entendidos como uma pequena coda da parte A.

Mais essencial do que a divisão em duas partes é a divisão da peça em frases, pois é esta a unidade estruturante principal. Aqui as frases são entendidas como unidades que contém sentido musical completo (o que inclui a ideia de início, meio e fim, sempre com algum tipo de processo cadencial) e também características sonoras peculiares. A intenção de frase em Contrastes está muito mais relacionada à concepção do performer do que ao texto, sendo que as decisões acerca de micromanipulações no tempo e dinâmica são os elementos mais relevantes para o estabelecimento da configuração fraseológica delimitada.

Como já mencionado, as frases contrastam entre si, principalmente em termos de caráter, textura e registro. Entretanto, internamente existem contrastes entre os elementos sonoros de cada frase, o que gera uma configuração binária neste aspecto das mesmas. Os contrastes internos de cada frase se baseiam nos elementos já descritos, dinâmica e tipo de toque, sendo que em alguns casos as diferenças são prescritas pela compositora e em outros casos as diferenças foram fruto de decisões interpretativas, normalmente incentivadas por mudanças na textura ou registro. $\mathrm{Na}$ tabela abaixo serão delimitados as frases e os sintagmas e também exemplificados os contrastes sonoros vinculados à performance existentes em cada frase:

\begin{tabular}{|c|c|c|c|c|}
\hline Frase & \multicolumn{2}{|l|}{ Sintagmas } & \multirow{2}{*}{\multicolumn{2}{|c|}{$\begin{array}{l}\text { Elementos de contraste sonoro na } \\
\text { performance } \\
\text { Toque legato com o pedal da direita versus } \\
\text { toque staccato sem pedal }\end{array}$}} \\
\hline A1 (1-6) & A1.1 (1-5) & A1.2 (5-6) & & \\
\hline A2 $\left(7-10^{2}\right)$ & A2.1 (7-8) & A2.2 (9-10) & \multicolumn{2}{|c|}{$\begin{array}{l}\text { Toque com velocidade de ataque mais } \\
\text { rápida versus toque com velocidade de } \\
\text { ataque mais lenta, ambos com uso do pedal } \\
\text { da direita }\end{array}$} \\
\hline A3 (10-163) & A3.1 (10-12) & A3.2 (13-14) & $\begin{array}{l}\text { A3.3 (15- } \\
16)\end{array}$ & $\begin{array}{l}\text { Toque com velocidade de } \\
\text { ataque mais rápida com pedal } \\
\text { da direita versus toque com } \\
\text { velocidade de ataque mais baixa } \\
\text { sem o pedal da direita e com uso } \\
\text { do pedal una corda }\end{array}$ \\
\hline A4 (164-21) & A4.1(16-20) & A4.2 (21) & \multicolumn{2}{|c|}{$\begin{array}{l}\text { Toque com velocidade de ataque mais } \\
\text { rápida versus toque com velocidade de }\end{array}$} \\
\hline
\end{tabular}

\footnotetext{
${ }^{2}$ A frase A2 vai até a fermata do c. 10.

${ }^{3}$ A frase A3 vai até a fermata do c. 16.

${ }^{4}$ A frase A4 se inicia após a fermata do c. 16, no "a tempo".
} 
MUSICA THEORICA Revista da Associação Brasileira de Teoria e Análise Musical 2018, v. 3, n. 2, p. 1-45 - Journal of the Brazilian Society for Music Theory and Analysis @ TeMA 2018 - ISSN 2525-5541

\begin{tabular}{|c|c|c|c|c|}
\hline & & & \multicolumn{2}{|c|}{$\begin{array}{l}\text { ataque mais lenta, ambos com uso do pedal } \\
\text { da direita }\end{array}$} \\
\hline A5 (22-27) & A5.1 (22-23) & A5.2 (24) & $\begin{array}{l}\text { A5.3 (25- } \\
27)\end{array}$ & $\begin{array}{l}\text { Toque legato com pedal versus } \\
\text { toque staccato sem pedal }\end{array}$ \\
\hline A6 (27-34) & A6.1 (27-32) & A6.2 (335-34) & \multicolumn{2}{|c|}{$\begin{array}{l}\text { Toque legato com pedal versus toque legato } \\
\text { sem pedal }\end{array}$} \\
\hline B1 $\left(35-41^{6}\right)$ & B1.1 (35-36) & B1.2 (37-41) & \multicolumn{2}{|c|}{$\begin{array}{l}\text { Toque legato versus toque staccato, ambos } \\
\text { com uso do pedal da direita }\end{array}$} \\
\hline B2 (417-46) & B2.1 (41-43) & B2.2 (44-45) & B2.3 $\left(46^{8}\right)$ & $\begin{array}{l}\text { Toque com velocidade de } \\
\text { ataque mais rápida versus toque } \\
\text { com velocidade de ataque mais } \\
\text { lenta, ambos com uso do pedal } \\
\text { da direita }\end{array}$ \\
\hline B3 (47-52) & B3.1 (47-51) & B3.2 (52) & \multicolumn{2}{|c|}{$\begin{array}{l}\text { Toque com velocidade de ataque mais } \\
\text { rápida com uso do pedal da direita versus } \\
\text { toque com velocidade de ataque mais lenta } \\
\text { com uso do pedal da direita e do pedal una } \\
\text { corda }\end{array}$} \\
\hline B4 (53-55) & B4.1 (53) & B4.2 (54-55) & \multicolumn{2}{|c|}{$\begin{array}{l}\text { Toque com velocidade de ataque mais } \\
\text { rápida versus toque com velocidade de } \\
\text { ataque mais lenta, ambos com o pedal da } \\
\text { direita }\end{array}$} \\
\hline B5 (56-61) & B5.1 (56-57) & B5.2 (58-61) & \multicolumn{2}{|c|}{$\begin{array}{l}\text { Toque com velocidade de ataque mais } \\
\text { rápida versus toque com velocidade de } \\
\text { ataque mais lenta, ambos com uso do pedal } \\
\text { da direita }\end{array}$} \\
\hline B6 (62-69) & B5.1 (62-65) & B5.2 (66-69) & \multicolumn{2}{|c|}{$\begin{array}{l}\text { Toque com velocidade de ataque mais } \\
\text { rápida com uso do pedal da direita versus } \\
\text { toque com velocidade de ataque mais lenta } \\
\text { com uso do pedal da direita e do pedal una } \\
\text { corda }\end{array}$} \\
\hline
\end{tabular}

Tabela 1: Divisão de frases e sintagmas em Contrastes

A tabela demonstra a variedade de combinações entre toques e utilização dos pedais nesta interpretação de Contrastes, exemplificando a maneira como ocorrem as interferências performáticas na construção da sonoridade da peça. A partir destas decisões interpretativas, aliadas à forma da peça e aos elementos da sonoridade contidos na escrita da mesma, seguir-se-á a apresentação da análise de tais elementos.

\footnotetext{
${ }^{5}$ A6.2 se inicia após o acorde prolongado do c. 32 .

${ }^{6}$ A finalização da frase B1 ocorre no dó central da mão direita no c. 41.

${ }^{7} \mathrm{O}$ início da frase B2 ocorre no Mi, da mão esquerda no c. 41.

${ }^{8}$ B2.3 se inicia no Sol, da mão esquerda no c. 46.
} 


\section{Análise da sonoridade em Contrastes}

Abaixo serão expostas as análises desta interpretação, seguindo de acordo com a divisão da peça em frases. Conforme definimos, cada frase apresenta uma estrutura de sintagma, com dois ou três momentos em relação de interdependência.

\subsection{A1}

A primeira frase da peça (cc. 1-6) é um sintagma composto de dois momentos sonoros. O primeiro, A1.1 vai do compasso 1 ao compasso 4 e se caracteriza por uma oposição entre a sonoridade das duas mãos, que executam duas vozes; a mão direita é executada em dinâmica $p$, com toque legato e com velocidade de ataque lenta, enquanto a mão esquerda toca notas em ff e acentuadas, com velocidade de ataque mais rápida. No segundo momento, A1.2 (cc. 5-6), as duas mãos entram em conformidade de toque, ambas em dinâmica $m f$ e legato. O pedal da direita é utilizado nesta frase até o compasso 5 e então é retirado.

No que diz respeito à $\mathrm{V}$, em A1.1, observou-se uma diferenciação em seus valores nos dois momentos sonoros detectados, como exemplificado no Gráfico 1 :

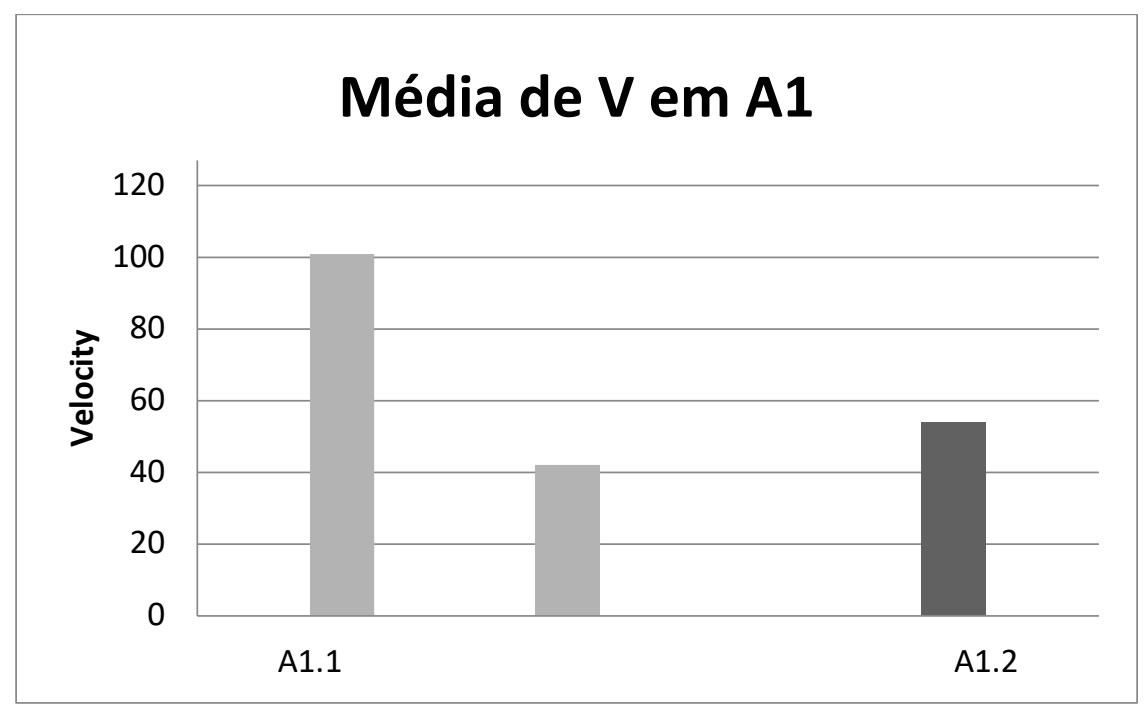

Gráfico 1: Médias de V em A1

Em A1.1, V se mostrou bastante diferente entre as duas mãos, apresentando valor médio de 101 para a mão esquerda (primeira coluna do gráfico) e 42 para a mão direita. Em A1.2, quando as mãos entram em 
conformidade e a dinâmica é $m f, \mathrm{~V}$ apresenta a média de 54, valor mais alto do que a mão direita em A1.1 e mais baixo do que a mão esquerda no mesmo trecho. As alterações nos valores médios do parâmetro velocity remetem diretamente às diferenciações de dinâmica e de toque. Outro fator relevante na constituição do toque é o tempo de cada nota; enquanto as semicolcheias do compasso 5 tiveram tempo de duração médio de $253 \mathrm{~ms}$, a semicolcheia e as colcheias do compasso 6 (em staccato) tiveram média de duração de $50 \mathrm{~ms}$. Assim, o tempo de manutenção da tecla abaixada, que se relaciona com o tipo de toque empregado, também atuou aqui como fator de aumento ou diminuição da ressonância.

Abaixo será apresentado o Gráfico 2 que mostra a evolução de $Q$ nas duas unidades:

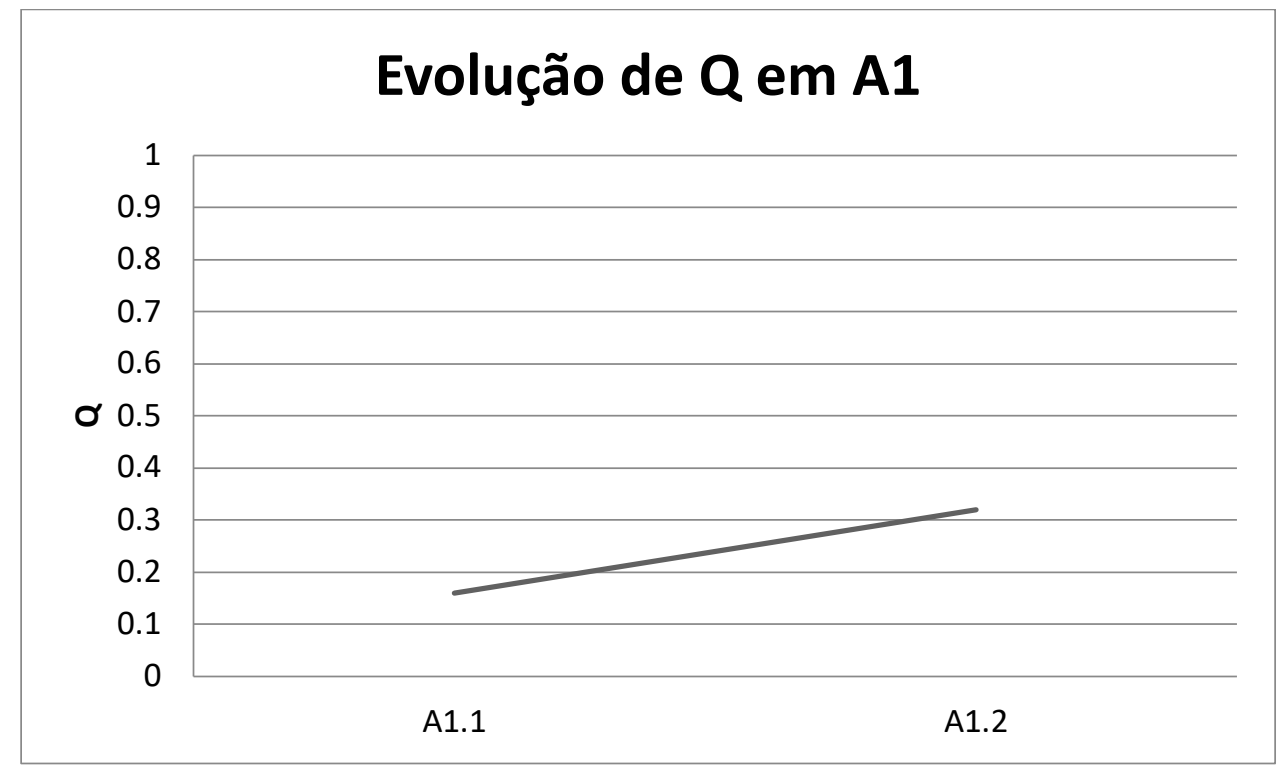

Gráfico 2: Evolução de Q em A1

Aqui, tem-se o valor das médias de $Q$ para cada momento de A1, sendo possível observar uma progressiva elevação de seu valor. Como o cálculo deste valor leva em consideração o registro, visto que é um elemento relevante na constituição tímbrica do instrumento, o aumento progressivo de $Q$ está relacionado diretamente com o caminho progressivo de uma região mais aguda para uma região mais grave neste trecho. Apesar da retirada do pedal da direita no fim de A1.2, o valor de $\mathrm{Q}$ aumentou, pois, este momento ocorre no registro mais grave do piano. Porém, a retirada do pedal, fez com que o valor de $Q$ continuasse relativamente baixo para o registro grave. 
Analisando a imagem do espectrograma na Figura 1, pode-se observar a correspondência entre as informações obtidas a partir do MIDI e o som criado.

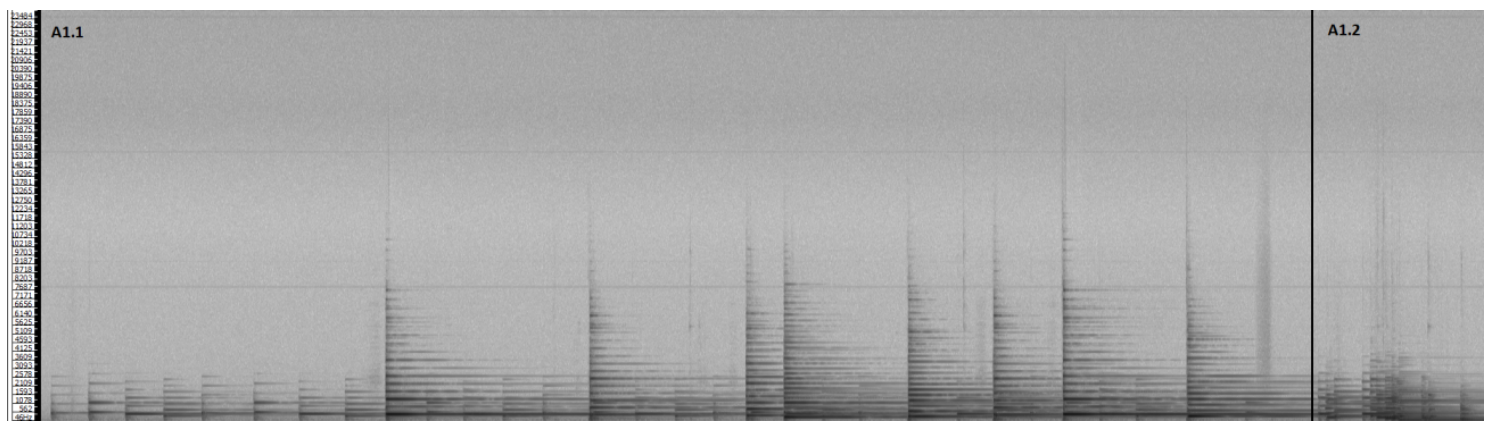

Figura 1: Espectrograma de A1

As linhas mais intensas, que indicam maior presença de harmônicos e sua maior intensidade, aparecem em A1.1, correspondendo às notas executadas pela mão esquerda, em dinâmica ff e com acentos. As notas da mão direita nesta unidade possuem uma qualidade tímbrica com menor número de harmônicos soantes.

Comparando as duas unidades de A1, vê-se que A1.1 conta com mais harmônicos soando enquanto em A1.2 há menor número e intensidade dos mesmos. Estes dados observados remetem à velocidade de ataque mais elevada da mão esquerda em A1.1, que ocasiona as linhas mais intensas. Seguindo, a diminuição em A1.2 se refere ao velocity mais baixo e à dinâmica inferior.

A Figura 2 demonstra o comportamento do centroide espectral em A1. Os oito picos elevados em A1.1 representam as oito notas executadas pela mão esquerda, mostrando que sua velocidade de ataque elevada trouxe o centro de massa do espectro para regiões mais agudas, ocasionando um som mais brilhante. Em A1.2 há uma significativa diminuição de $\mathrm{CE}$, porém ainda se mantendo mais alta do que nos momentos entre os picos de A1.1. No fim de A1.2 aparecem os menores valores de $\mathrm{CE}$, o que corresponde ao velocity baixo do trecho, duração curta das notas e ausência do pedal da direita. 


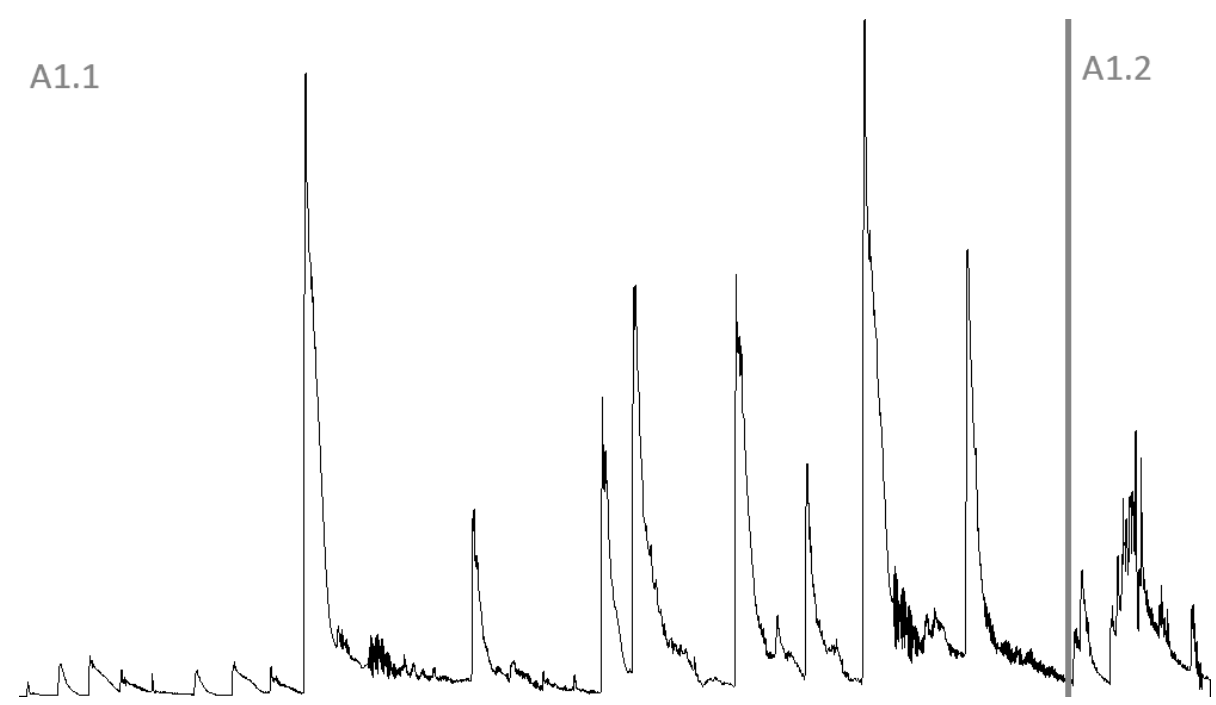

Figura 2: Centroide espectral em A1

\section{$6.2 \mathrm{~A} 2$}

A frase A2 (cc. 7-10) é um sintagma composto de duas unidades contrastantes: a primeira dura dois compassos (7 e 8) e se caracteriza por uma dinâmica $m f$ e $f$, com velocidade de ataque rápida; a unidade seguinte (cc. 9-10) contrasta com anterior pela velocidade de ataque mais lenta, em busca de um som mais sutil, com dinâmica inferior e timbre mais opaco. Houve a decisão também de deixar tempo mais lento em A2.2, com o intuito de criar um contraste ainda maior. Em toda esta frase o pedal da direita é acionado ininterruptamente, não havendo qualquer alteração nesse aspecto da sonoridade. Na análise de $\mathrm{V}$, é possível verificar a diferença considerável dos valores em A2.1 e A2.2, como ilustrado no Gráfico 3:

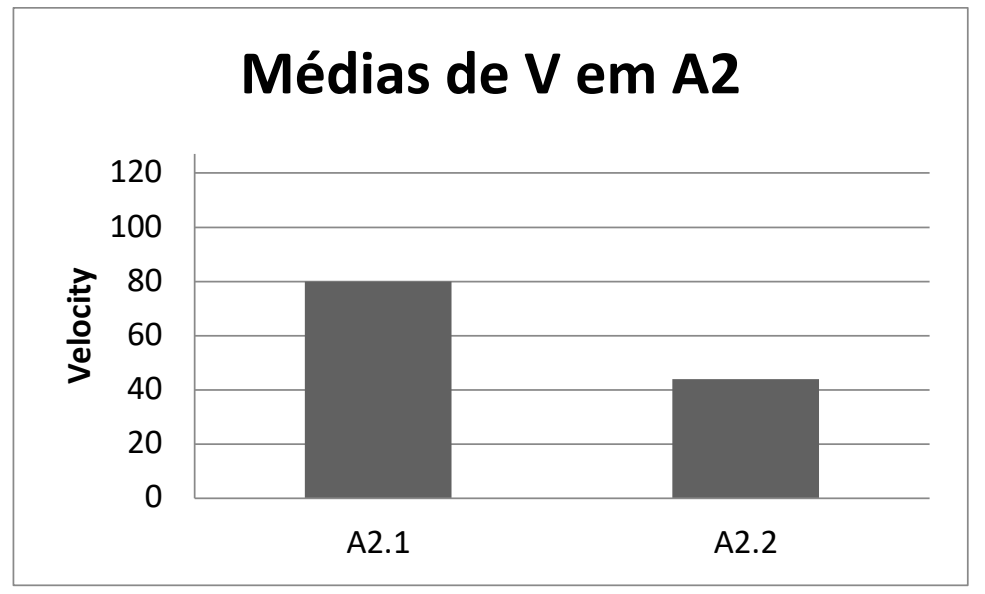

Gráfico 3: Médias de V em A2 
Enquanto a primeira unidade tem uma média de $\mathrm{V}$ de 80 , a segunda contabiliza uma média de 43, sendo a segunda quase metade da primeira. Essa diferença verifica a execução efetiva do intento interpretativo. No Gráfico 4 se vê a evolução do valor de $Q$ nesta frase:

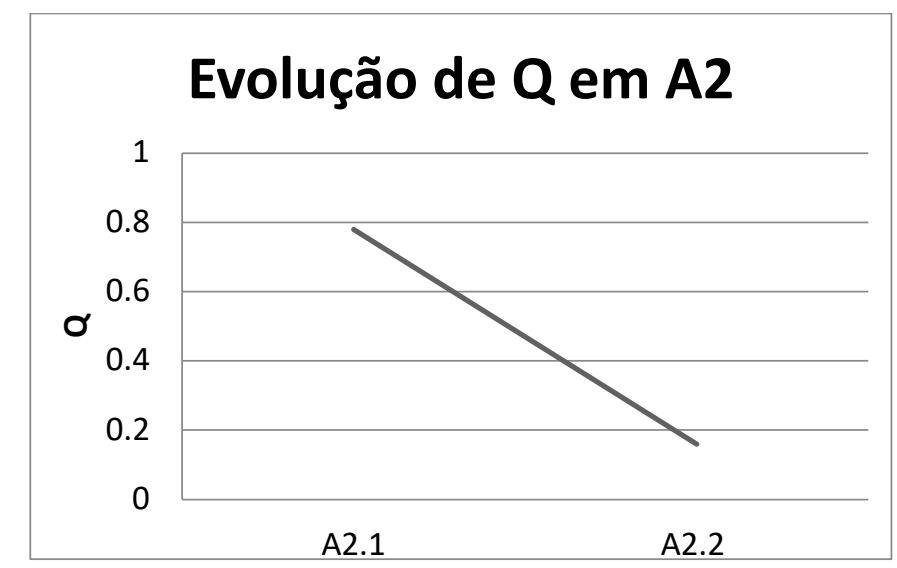

Gráfico 4: Evolução de Q em A2

A baixa do valor de $Q$ de 0,78 para 0,16 é explicada por dois fatores: (1) a mudança do registro grave em A2.1 para o registro agudo em A2.2; e (2) a diminuição significativa do valor do velocity.

Observando o espectrograma na Figura 3, é perceptível a presença bastante intensa de harmônicos audíveis, principalmente na sessão central de A2.1, onde ocorre o ápice dinâmico e da ressonância do pedal da direita acionado no início do trecho e sem trocas. Em contrapartida em A2.2 fica quase imperceptível o registro dos harmônicos audíveis, demonstrando no sinal sonoro os valores de $Q$.

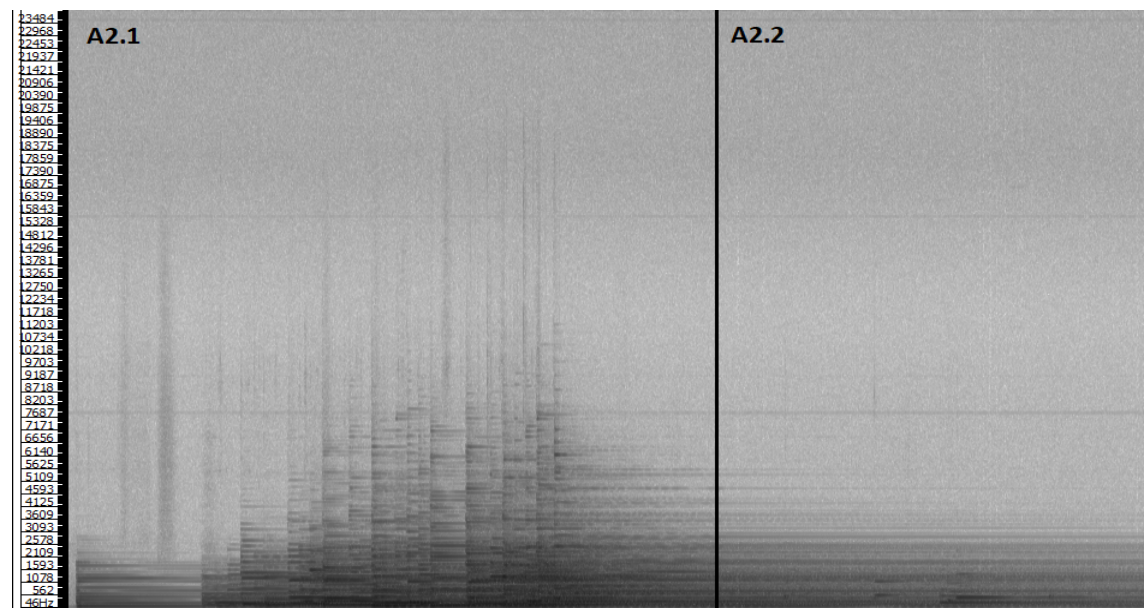

Figura 3: Espectrograma de A2 
Na Figura 4 de CE um comportamento análogo é percebido:

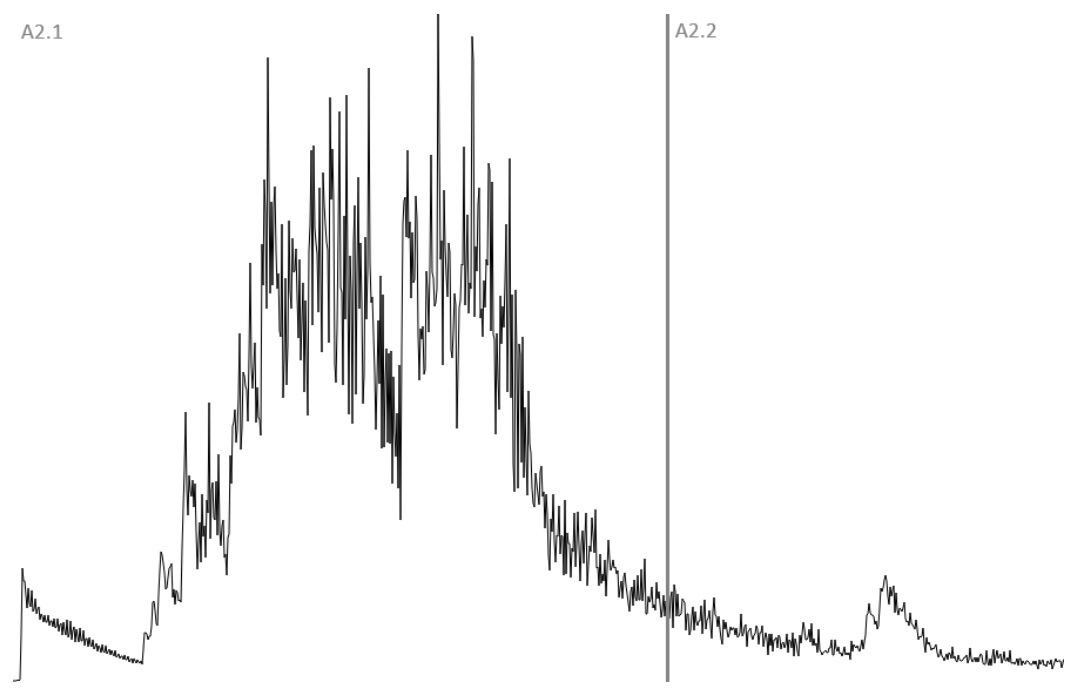

Figura 4: Centroide espectral em A2

Em A2.1 os valores são bastante altos, sobretudo na parte central do trecho, enquanto em A2.2 a diminuição é bastante grande, demonstrando a presença de uma sonoridade com menos brilho. Apesar de ocorrer em um registro mais agudo, A2.2 possui o centro de massa nas frequências mais graves, em decorrência principalmente do baixo valor de V.

\section{$6.3 \mathrm{~A} 3$}

A frase A3 (cc. 10-16) se caracteriza por um sintagma em três partes, sendo que a primeira e a terceira parte correspondem à uma mesma sonoridade no instrumento e a segunda corresponde ao elemento contrastante, revelando a seguinte configuração: A3.1 (cc. 10-12), um momento sonoro contrastante em A3.2 (cc. 13-14) e o retorno às características sonoras iniciais da performance em A3.3 (cc. 15-16). O primeiro e o terceiro momentos se caracterizam por uma sonoridade que varia entre $m f$ e $f$, toque legato e pedal da direita acionado ininterruptamente, criando ressonâncias. $O$ trecho contrastante, A3.2, se identifica pela dinâmica $p$ e indicação de "sem pedal" na partitura. Além destes elementos, optou-se por utilizar o pedal una corda neste trecho, para criar um contraste de timbres ainda maior, levando em consideração que o acionamento deste pedal modifica o timbre global, além de contribuir para a diminuição da intensidade. 
No Gráfico 5 são mostrados os valores médios de V nos três momentos de A3:

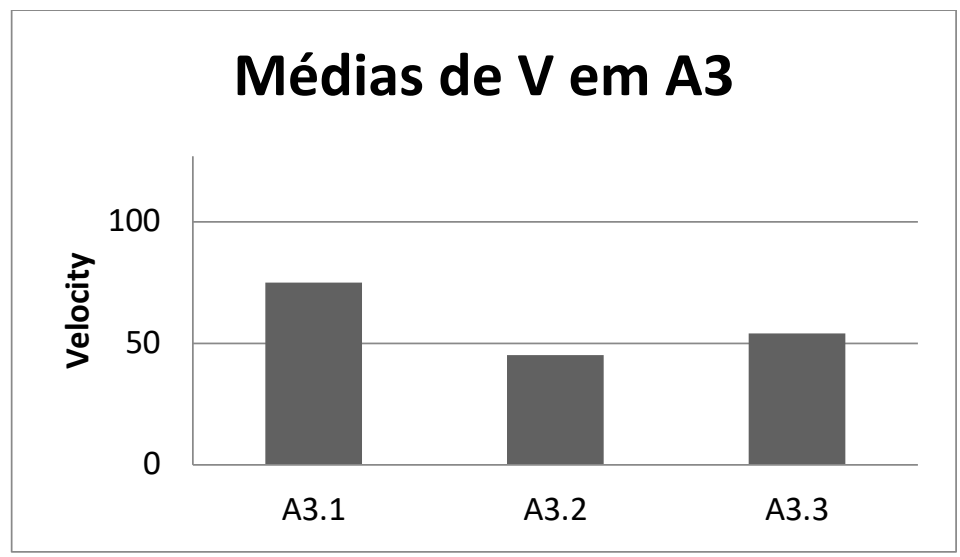

Gráfico 5: Médias de V em A3

O primeiro trecho apresenta média de 74 em A3.1, seguida de 45 em A3.2 e 54 em A3.3. Estes dados demonstram consistência com os intentos interpretativos para o trecho, buscando um valor menor de $\mathrm{V}$ no momento central.

Os valores de $Q$ também corroboram com as intenções para o trecho (Gráfico 6):

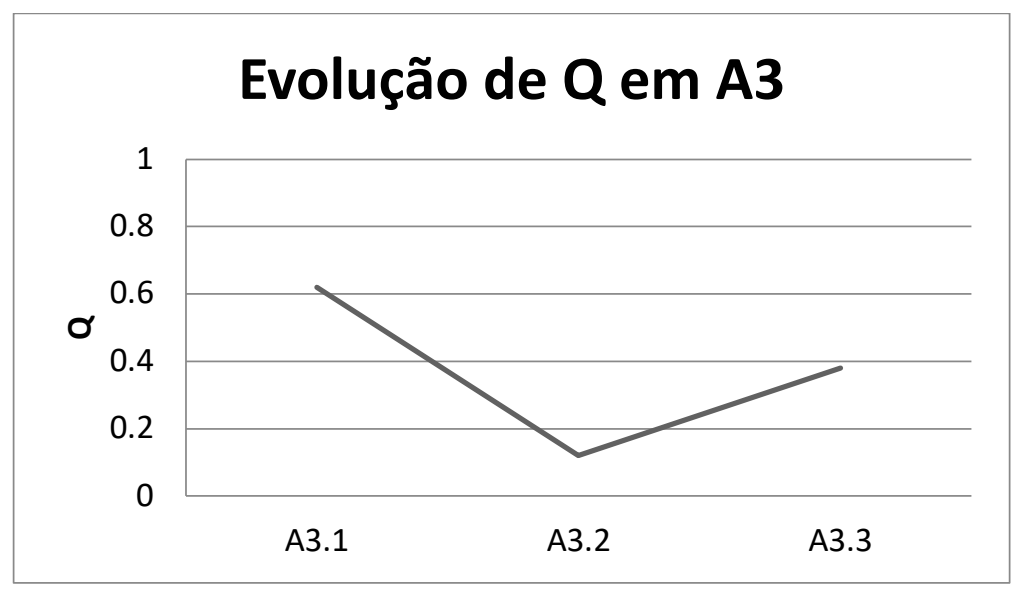

Gráfico 6: Evolução de Q em A3

Estes resultados também apresentam um valor maior para A3.1, de 0,62, o menor valor em A3.2, de 0,12 e uma elevação em A3.3 para 0,38. A diminuição abrupta do primeiro para o segundo trecho diz respeito à diminuição de $\mathrm{V}$, à utilização do pedal una corda e à retirada do pedal da direita. O registro em A3.2 é mais grave do que no momento precedente, porém os elementos modificados no toque e pedal ocasionaram a baixa da qualidade tímbrica neste trecho. Por 
fim, A3.2 incrementa um pouco o valor de $Q$, sobretudo pelo acionamento do pedal da direita e velocidade de ataque mais elevada, uma vez que o registro permanece similar ao de A3.2.

$\mathrm{O}$ valor $\mathrm{Q}$ em $\mathrm{A} 3$ demonstrou como as alterações de toque (velocity) e pedalização produziram alterações significativas na qualidade tímbrica dos trechos, sendo os elementos principais da criação de contraste sonoro neste momento.

O espectrograma trazido na Figura 5 corrobora com os dados extraídos dos arquivos MIDI, demonstrando que as alterações na abordagem instrumental tiveram resultados análogos no sinal sonoro.

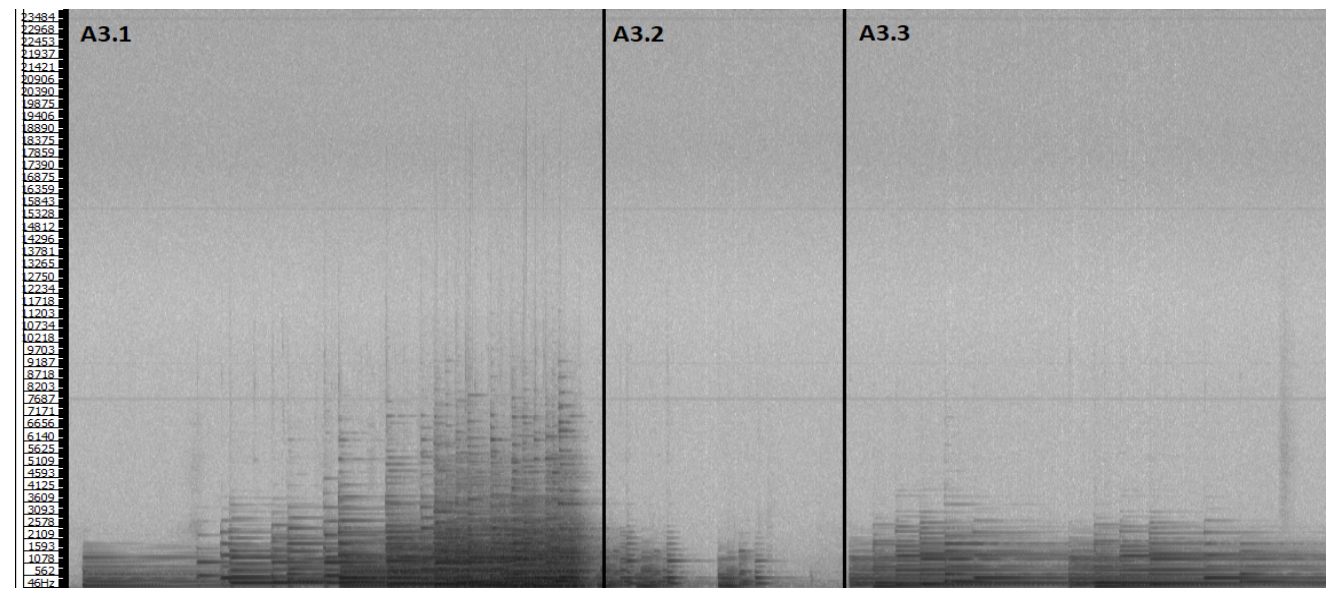

Figura 5: Espectrograma de A3

O primeiro momento é o de maior intensidade de harmônicos audíveis (principalmente nos harmônicos mais graves) e também o trecho com maior quantidade dos mesmos. No trecho seguinte, A3.2, há uma queda na quantidade e intensidade destes harmônicos, que em A3.3 é recuperada, demonstrando novamente uma presença mais relevante desta informação.

Os valores de CE trazidos na Figura 6 também mostram um valor mais elevado em A3.1, que sofre uma queda significativa em A3.2 e depois se eleva em A3.3. A drástica queda nos valores comparando A3.1 e A3.2 demonstram o efetivo contraste realizado. O desenho dos picos menos ranhurados em A3.2 é ocasionado pela temporalidade, sendo que cada ataque foi realizado mais longe temporalmente um do outro. Isso é explicável pela diferença na duração das notas, já que em A3.2 as fusas tiveram duração média de $400 \mathrm{~ms}$, enquanto em A3.2 a média foi de $179 \mathrm{~ms}$ e em A3.3 de $9109 \mathrm{~ms}$. Essa grande diferença é parte da caracterização dos toques empregados, sendo que em A3.1 e A3.3 houve maior 
tempo de contato do dedo com a tecla e em A3.2 o tempo foi menor, afim de gerar o mínimo possível de ressonância.

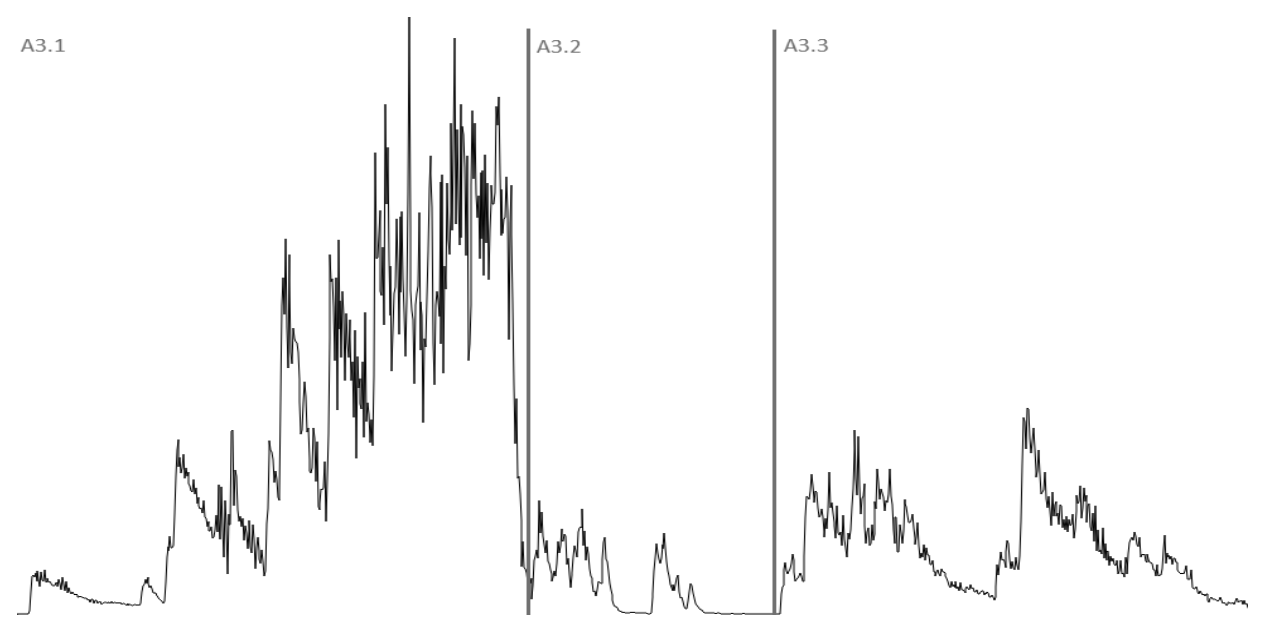

Figura 6: Centroide espectral em A3

Em todos os dados trazidos foi possível detectar uma grande diferença entre A3.1 e A3.2 e uma diferença menor entre A3.2 e A3.3, sendo que os valores tanto de $\mathrm{V}$, quanto de $\mathrm{Q}$, ou mesmo no número de harmônicos presentes ou nos valores de $\mathrm{CE}$, se manifestaram sempre mais elevados para A3.1 do que para A3.3. Isso demonstra que a sonoridade inicial não foi de fato resgatada, mas houve um prenúncio deste resgate.

\section{$6.4 \mathrm{~A} 4$}

A frase A4 (cc. 16-21) compõe-se por um sintagma com dois momentos sonoros; o primeiro deles, A4.1 (cc. 16-20), caracteriza-se por uma dinâmica ff, toque legato e velocidade de ataque rápida, visando uma sonoridade brilhante. No segundo momento, A4.2 (cc. 21), há uma mudança de registro (do superagudo para o médio) e de fluxo temporal (das fusas predominantes, semicolcheias e colcheias em A4.1 passa-se a colcheias pontuadas em uma textura cordal). Essas diferenciações da escrita levaram à decisão de executar A4.2 com uma velocidade de ataque mais lenta, buscando uma dinâmica próxima à $p$ e um som menos brilhante do que em A4.1. Em toda a frase A4 houve a utilização ininterrupta do pedal da direita, sem qualquer alteração neste aspecto. 
MUSICA THEORICA Revista da Associação Brasileira de Teoria e Análise Musical 2018, v. 3, n. 2, p. 1-45 - Journal of the Brazilian Society for Music Theory and Analysis@ TeMA 2018 - ISSN 2525-5541

Os dados de $\mathrm{V}$ trazidos no Gráfico 7 abaixo mostram o valor médio de 83 em A4.1 e 38 em A4.2, uma diferença relevante entre as duas abordagens de toque pianístico.

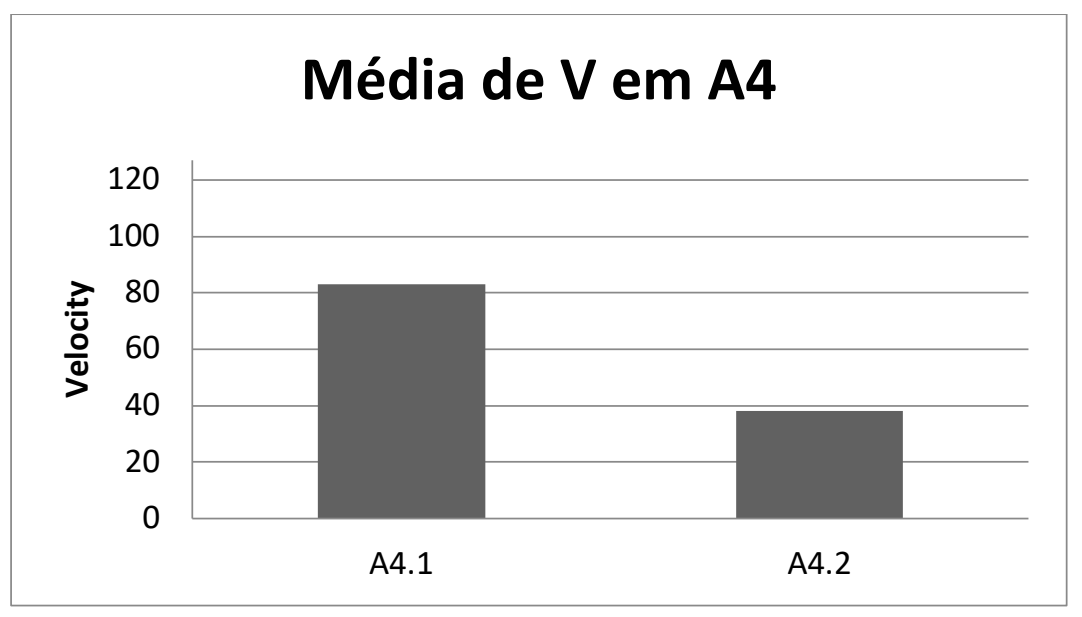

Gráfico 7: Médias de V em A4

Os valores de $Q$, por sua vez, mostram uma sutil elevação, contando um valor médio de 0,16 em A4.1 e de 0,18 em A4.2 (Gráfico 8).

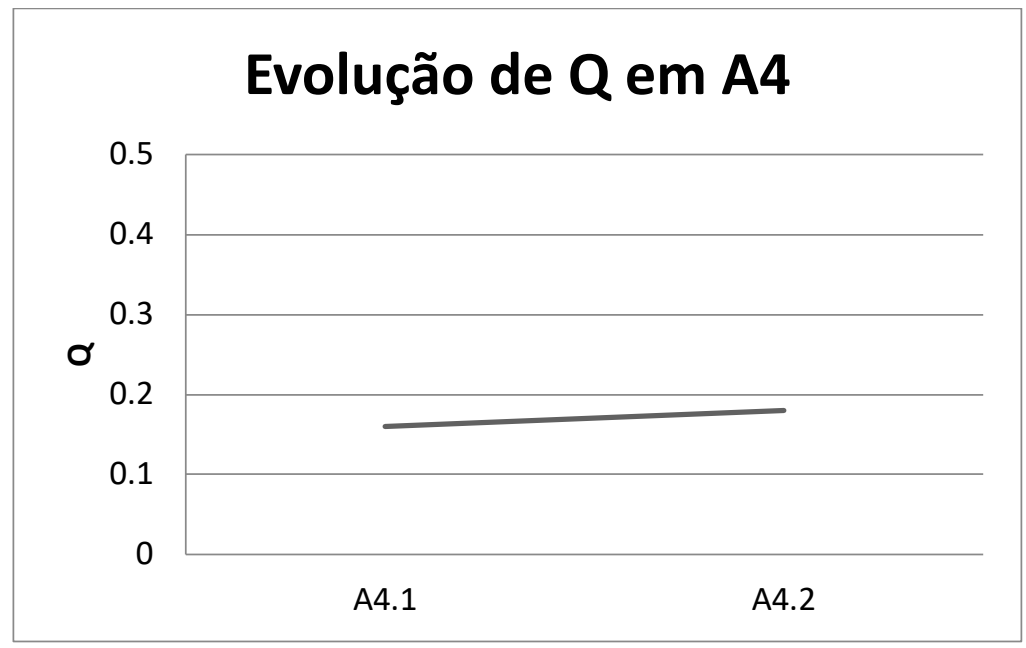

Gráfico 8: Evolução de Q em A4

O leve aumento de $\mathrm{Q}$ em $\mathrm{A} 4.2$ se deve à mudança de registro, passando de um registro mais agudo para outro mais grave, o que acrescenta valor no cálculo da qualidade tímbrica. Porém, o aumento de $Q$ em relação ao registro é neutralizado pela diminuição expressiva de $\mathrm{V}$, elemento que diminui valor tímbrico.

A análise do espectrograma trazido na Figura 7 demonstra uma grande quantidade de harmônicos soantes em A4.1, com linhas bastante intensas, 
revelando a presença relevante de tais elementos. Por outro lado, na parte da figura que se reporta à A4.2 é quase imperceptível a identificação dos harmônicos, sobretudo nos registros médios e agudos.

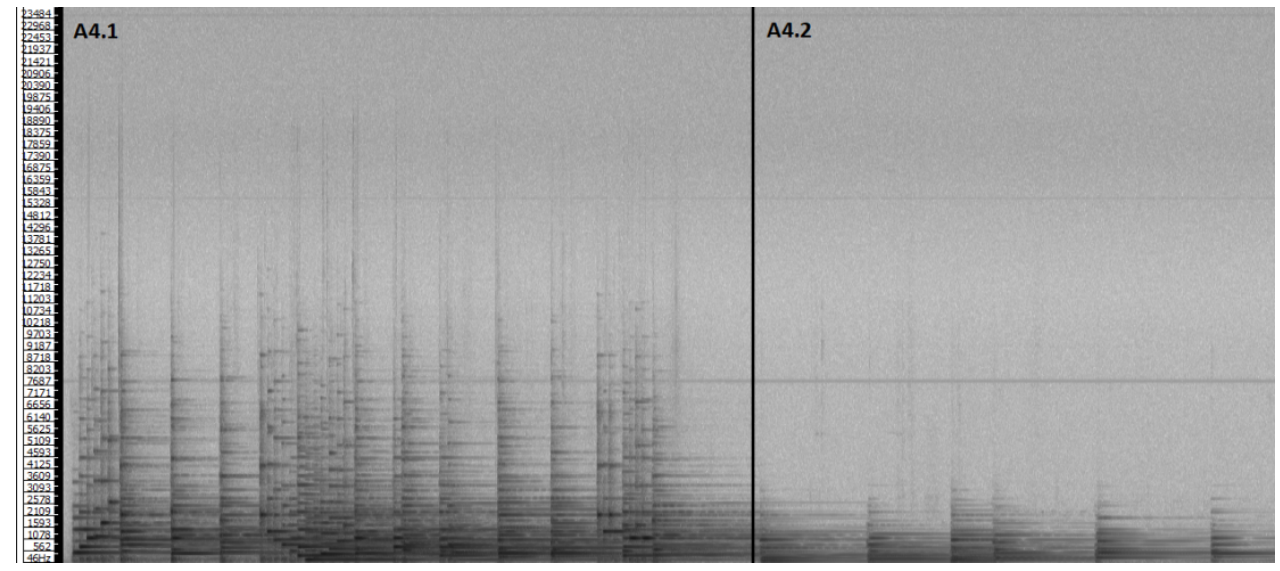

Figura 7: Espectrograma de A4

A imagem (Figura 8) que reporta os valores de CE também mostra valores mais elevados em A4.1 e valores consideravelmente mais baixos em A4.2. Tais valores remetem diretamente ao som mais brilhante pretendido no momento inicial e no contraste com uma sonoridade mais opaca no momento seguinte.

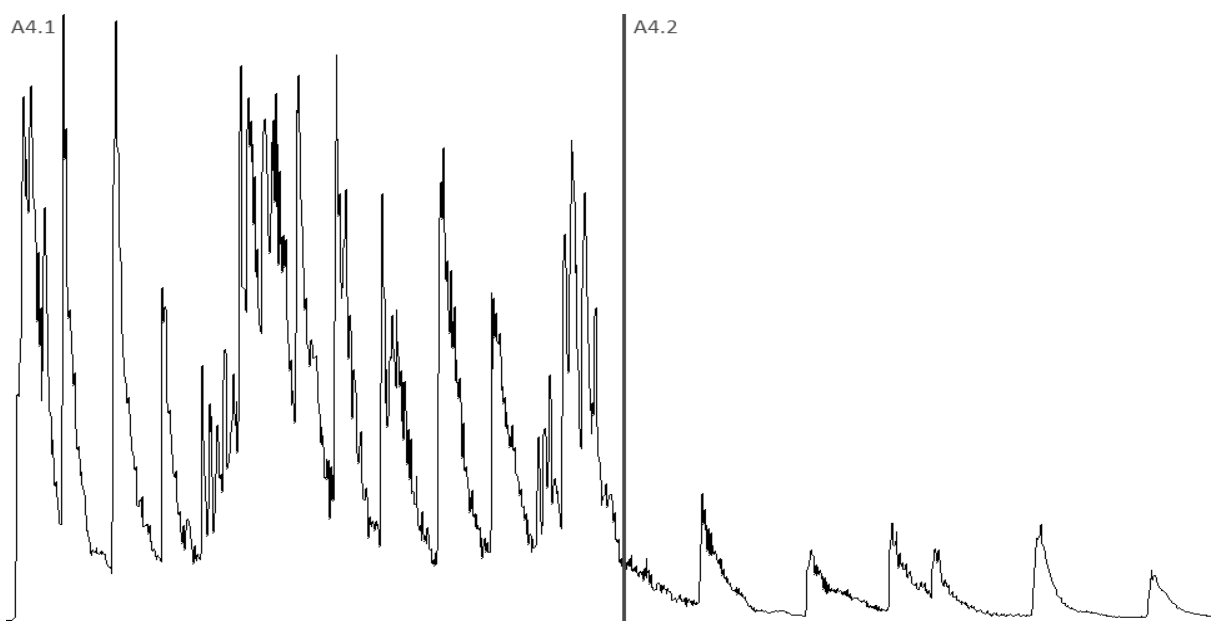

Figura 8: Centroide espectral em A4

\subsection{A5}

A frase A5 (cc. 22-27) é constituída por um sintagma com três momentos sonoros, A5.1 (cc.22-23), A5.2 (cc. 24) e A5.3 (cc. 25-27). O primeiro e último momento (A5.1 e A5.3) possuem características sonoras iguais; uma mesma 
textura de melodia na mão direita e notas duplas longas na mão esquerda, dinâmica $m f$, utilização do registro médio do piano, toque legato e pedal da direita acionado todo o tempo, sem trocas. O momento A5.2 contrasta dos outros dois de maneira bastante enfática, a textura passa a ser uma só linha melódica, sem acompanhamento, utilização do toque staccato, notas mais rápidas e registro super grave do instrumento. A fim de salientar a mudança sonora, para que houvesse um contraste entre um som com muitas ressonâncias em A5.1 e A5.3 e um som mais seco em A5.2, optou-se por retirar o pedal da direita neste momento e utilizar o pedal una corda.

O Gráfico 9 mostra os dados de $\mathrm{V}$ em A5, que contam com um valor médio de 46 para A5.1, que se repete em A5.3 e valor médio de 63 em A5.2. É evidente que a diferenciação do toque na seção central se deu por meio de um aumento na velocidade de ataque, que se manteve igual nos outros dois momentos.

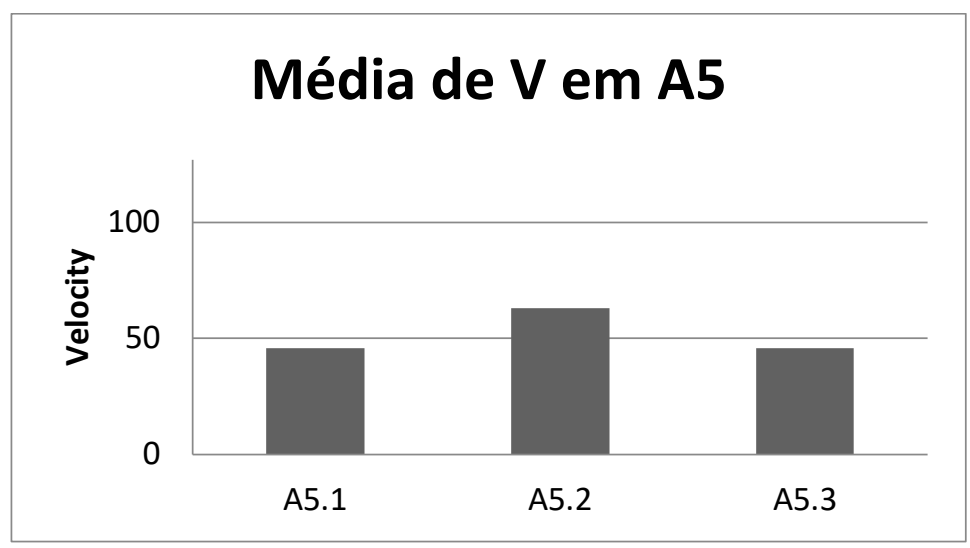

Gráfico 9: Médias de V em A5

Já os valores de $Q$ detectados, mostram uma oscilação muito baixa, sendo 0,24 em A5.1 e 0,2 em A5.2 e A5.3 (Gráfico 10).

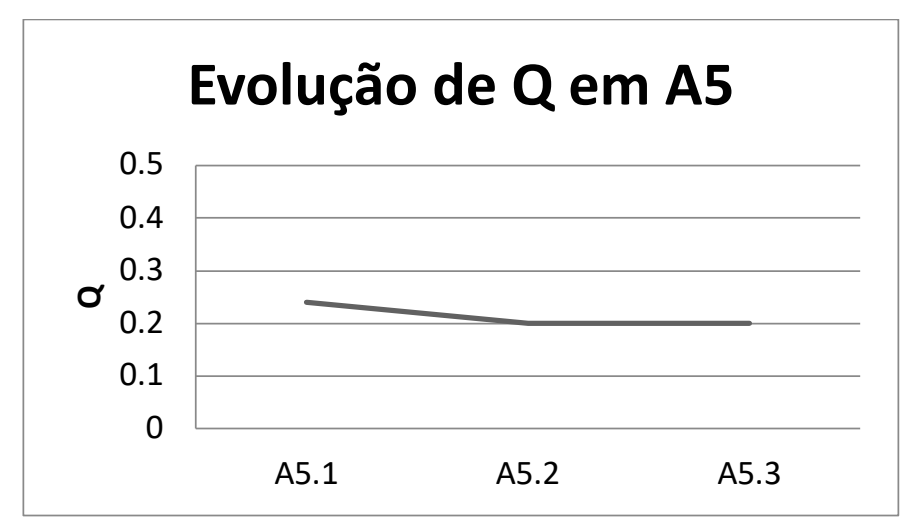

Gráfico 10: Evolução de Q em A5 
Estes resultados remetem às diferenciações interpretativas no trecho: apesar de A5.2 ocorrer em registro mais grave (o que acrescentaria valor à Q), e ter uma velocidade de ataque mais alta, não foi utilizado o pedal da direita e foi acionado o pedal una corda, que tira qualidade tímbrica em termos de harmônicos soantes. Assim, a velocidade de ataque mais baixa e registro mais agudo em A5.1 e A5.3 foram compensados em termos de qualidade do timbre por meio do uso do pedal da direita, que permite a ressonância tanto das cordas postas em vibração quanto das cordas que ressoam em simpatia. Assim, o aspecto determinante neste caso foi a escolha da pedalização no trecho.

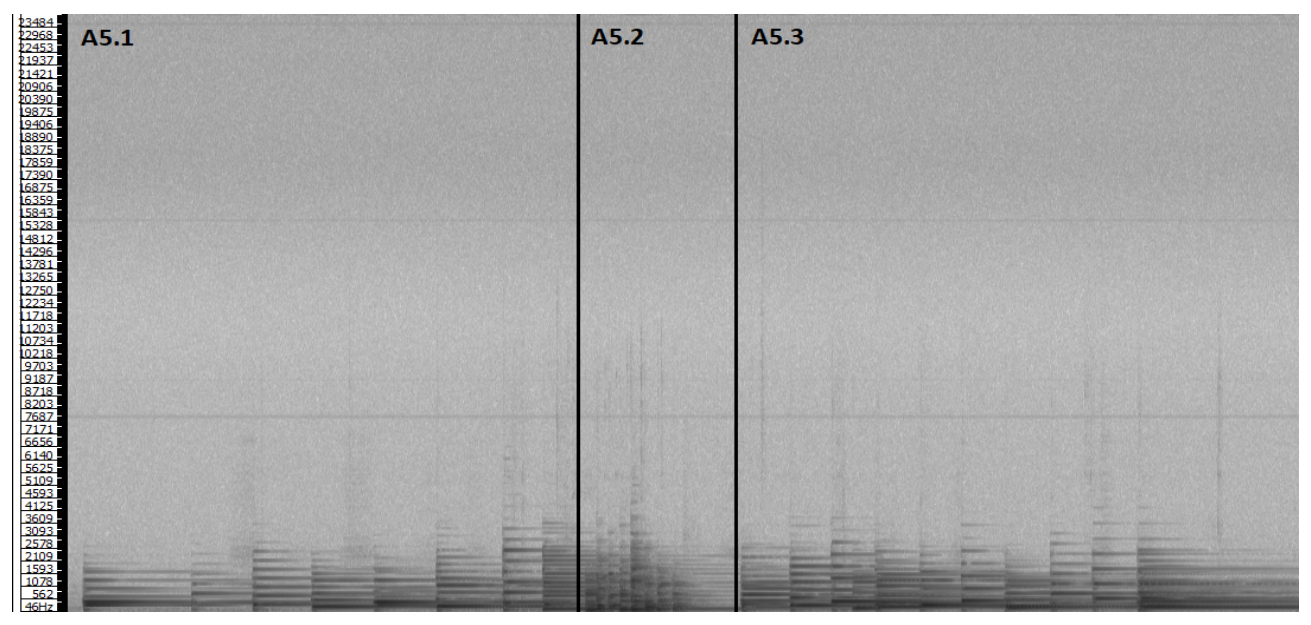

Figura 9: Espectrograma de A5

No espectrograma trazido na Figura 9, é possível observar a semelhança do comportamento, presença e intensidade dos harmônicos em A5.1 e A5.3 e sua alteração em A5.2, onde ocorre uma maior presença dos harmônicos graves e menor dos médios e agudos. Essa diferenciação remete tanto à pedalização, quanto à alteração de registro em A5.2.

Abaixo, na Figura 10, pode-se verificar a similaridade de A5.1 e A5.3 no que diz respeito à CE e alteração da mesma em A5.2. 


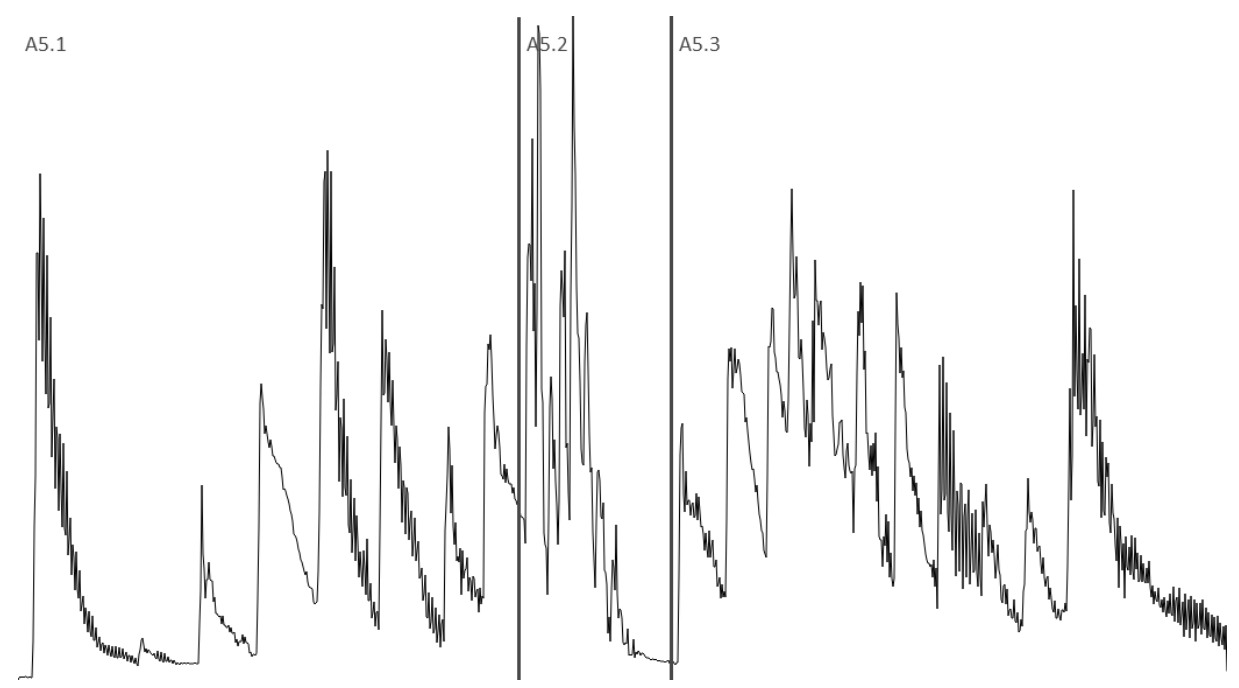

Figura 10: Centroide espectral em A5

Os picos menos ranhurados em A5.2 refletem a temporalidade; em A5.2 o tempo de duração da tecla abaixada nas semicolcheias foi menor em virtude do toque staccato, o que explica que as semicolcheias ocorridas em A5.3 tiveram duração média de 387ms, enquanto as semicolcheias de A5.2 tiveram média de $124 \mathrm{~ms}$. Em A5.2 ocorrem também os picos mais altos, que são consequência do velocity mais elevado. Então, apesar de ocorrer em registro mais grave, A5.2 apresentou os valores de centroide mais altos, identificando o centro de massa dos espectros em frequências mais agudas, ocasionando um som mais brilhante.

\subsection{A6}

A frase seguinte A6 (cc. 28-34) é um sintagma que se divide em dois momentos sonoros contrastantes, o primeiro deles, A6.1 (cc. 28-33) e o segundo A6.2 (c. 34). O primeiro momento é caracterizado sobretudo pela pedalização, que utiliza o pedal da direita de maneira ininterrupta. Além disso, a textura predominante, com acordes longos nas vozes mais agudas e interferências melódicas na voz mais grave, também distingue o trecho. No último compasso de A6.1 há uma alteração na textura, que já prenuncia a textura de A6.2, uma sequência melódica em semicolcheias. Porém, devido à pedalização que não se altera, o aspecto sonoro se mantém mais afim com o primeiro momento sonoro, sendo que somente com a retirada do pedal da direita é caracterizado um contraste sonoro. O segundo momento sonoro, como já explicitado, se identifica principalmente pela retirada do pedal da direita (indicada na partitura) aliada à dinâmica $p$ e menor duração do contato com as teclas, a fim de gerar o mínimo 
de ressonância possível. Então, A6.2 traz uma sonoridade mais seca e percussiva, em contraste com a grande ressonância gerada no momento precedente. As médias de $\mathrm{V}$ em $\mathrm{A} 6$ se mantem muito similares, sendo de 46 para A6.1 e 51 para A6.2. De fato, não houve intenção de alteração neste parâmetro na interpretação. Por outro lado, os valores de $\mathrm{Q}$ se mostraram diferentes, como observável no Gráfico 11:

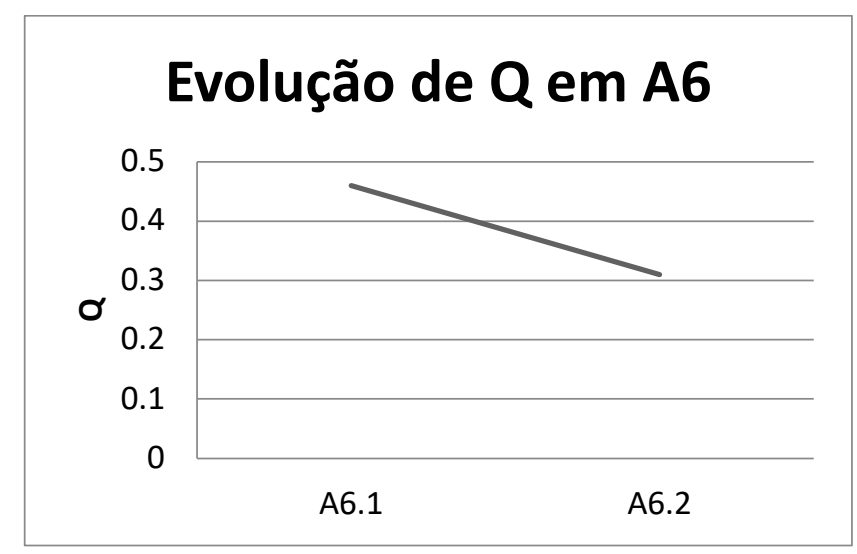

Gráfico 11: Médias de V em A6

Enquanto em A6.1 a média de Q foi de 0,46, em A6.2 ela decresceu para 0,31. Mantendo-se um V bastante similar e o mesmo registro, a causa desta diferenciação em termos de qualidade tímbrica foi a pedalização escolhida.

A Figura 11, do espectrograma, reflete em A6.2 uma maior presença de harmônicos audíveis, porém, se comparado às linhas verticais mais intensas em A6.1, em A6.2 elas aparecem com menor intensidade.

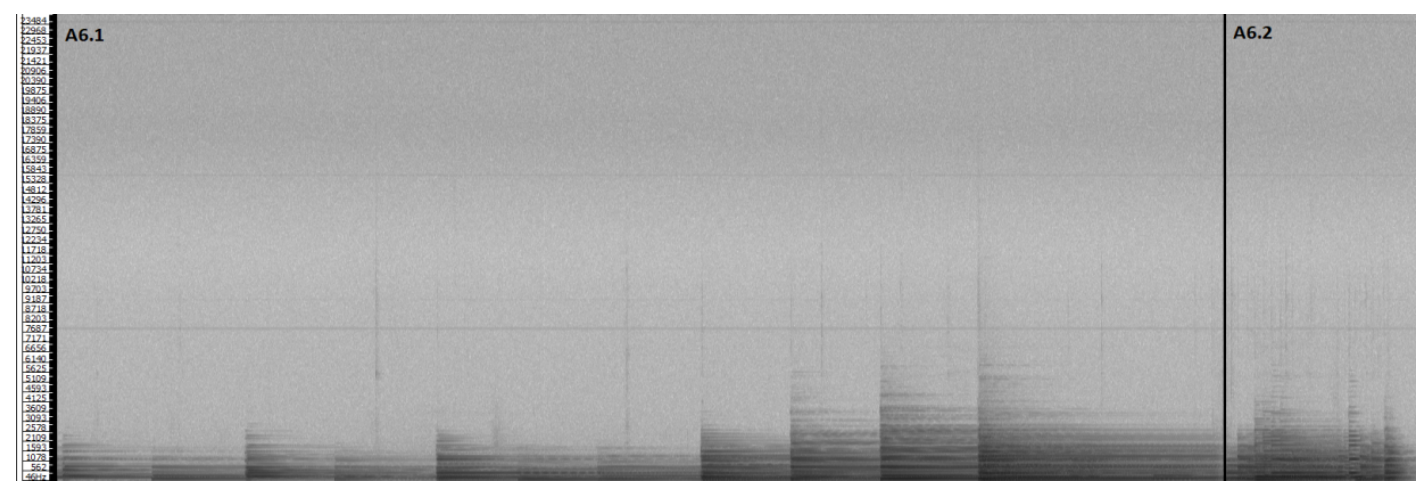

Figura 11: Espectrograma de A6

A6.1 teve menos menor presença de harmônicos, porém os que se manifestaram foram mais intensos. Essa diferenciação ocorreu principalmente em decorrência de $\mathrm{V}$ levemente mais elevado em A6.2, lembrando que uma maior velocidade de ataque gera mais ressonância (o que corresponde a um 
maior número de harmônicos), porém a ausência do pedal da direita fez com que esses harmônicos não fossem tão intensos, uma vez que terminada a ação do martelo na corda eles não continuariam vibrando.

Os dados trazidos pelos valores de CE em A6 (Figura 12) ilustram outra característica sonora; embora A6.2 tenha uma média de V levemente mais alta que A6.1, os valores de CE são mais baixos, novamente remetendo à não utilização do pedal da direita.

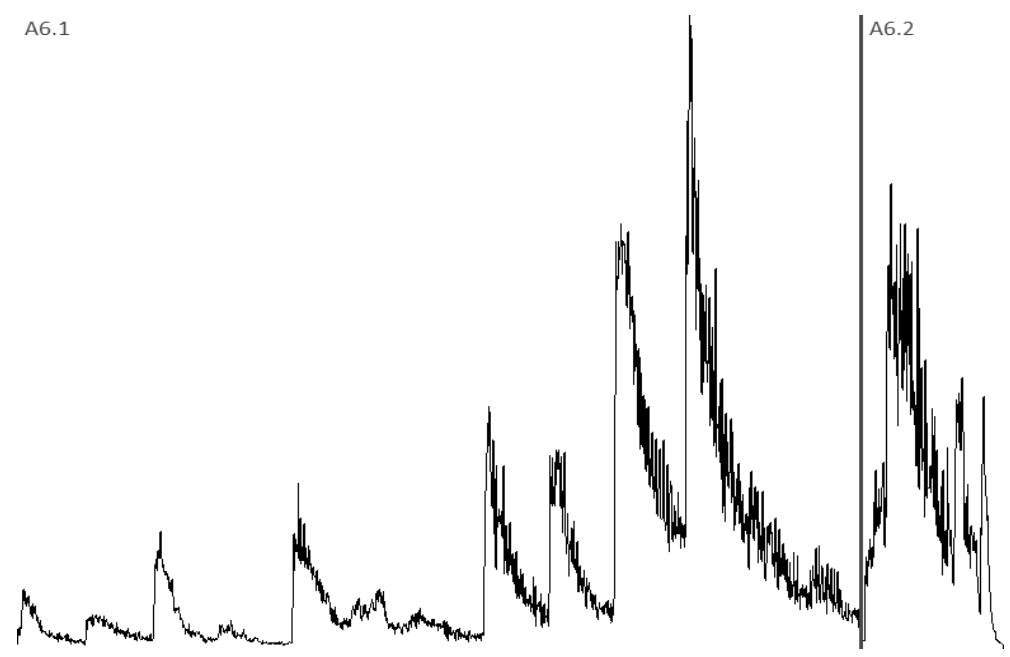

Figura 12: Centroide espectral em A6

\subsection{B1}

A primeira frase da segunda seção de Contrastes, B1 (cc. 35-41) é um sintagma que se divide em dois momentos sonoros distintos pela textura, registro e toque pianístico, sendo eles B1.1 (cc. 35-36) e B1.2 (cc.37-41). B1.1 se passa no registro grave e super grave do piano e nele há a utilização de um toque bastante legato, com velocidade de ataque baixa e intenção de não salientar cada ataque, mas sim neutralizar os ataques individuais de cada nota. O momento seguinte, B1.2, contrasta principalmente pela mudança de registro e articulação, passando de um toque legato para staccato. A principal diferenciação pretendida em termos de toque pianístico se deu na velocidade de ataque; enquanto em B1.1 intendeuse não evidenciar os ataques individuais, optou-se por uma velocidade de ataque mais lenta, enquanto em B1.2 houve a intenção de criar um som com mais brilho e evidenciando os ataques, através de uma velocidade de ataque mais rápida. Em B1 o pedal da direita foi utilizado em tempo integral, sem trocas. 


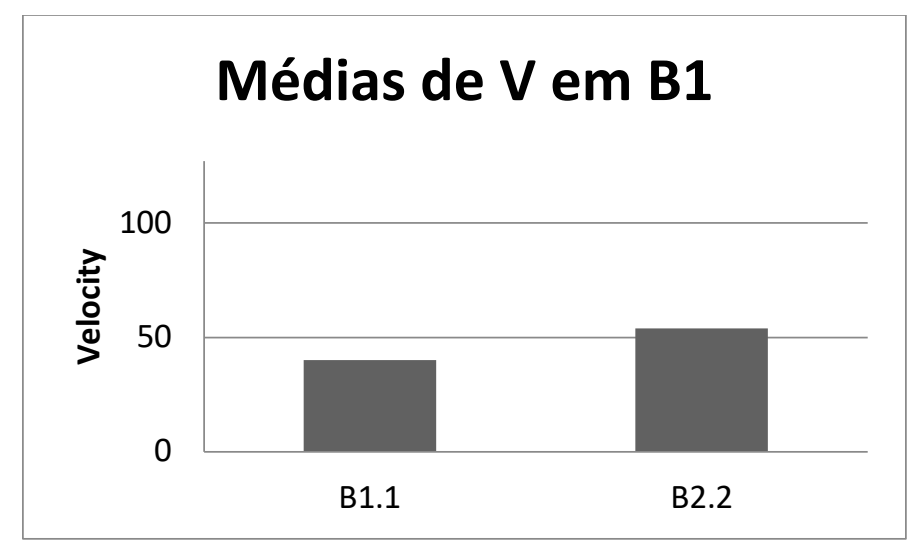

Gráfico 12: Médias de V em B1

O Gráfico 12 acima mostra uma média de V de 40 para B1.1 e de 54 para B1.2, confirmando a realização dos intentos interpretativos, de um toque com menor $\mathrm{V}$ no primeiro momento e vice-versa no segundo momento.

Entretanto, ao observar a evolução de Q em B1, vê-se uma diminuição de 0,48 em B1.1 para 0,26 em B1.2. Esta queda, apesar da elevação da velocidade de ataque se deu em virtude da mudança drástica de registro, que passou do grave e super grave para os registros agudo e superagudo. Assim, levando em consideração a constituição tímbrica do instrumento, que se altera conforme o registro, por mais que a velocidade de ataque tenha sido mais elevada em B1.2, sua qualidade tímbrica foi mais baixa, devido ao registro utilizado (Gráfico 13).

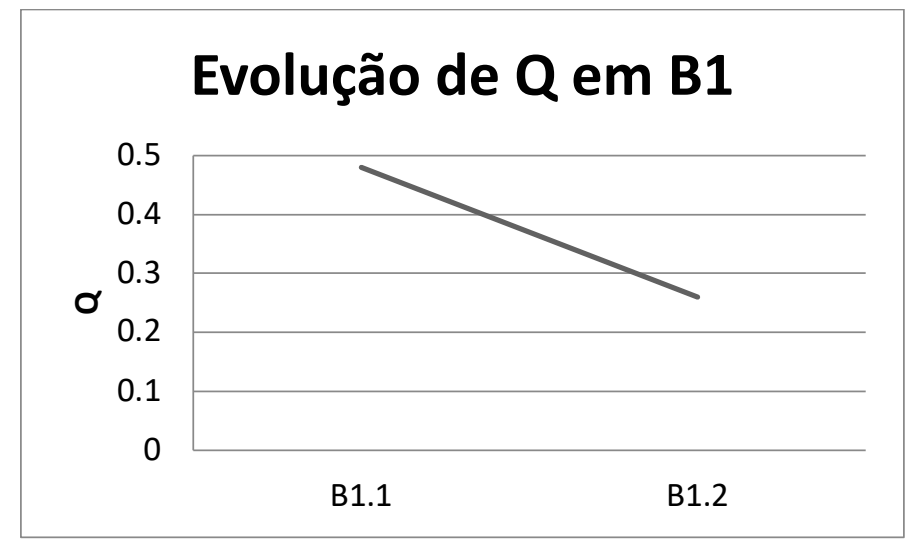

Gráfico 13: Evolução de Q em B1

O espectrograma de B1 (Figura 13) mostra informações interessantes, onde é possível observar uma similaridade no espectro de B1.1 e o início de B1.2 e um aumento na intensidade e presença de harmônicos do meio para o fim de B1.2 Primeiramente, a similaridade inicial remete ao registro grave aliado à $\mathrm{V}$ mais baixo e ao registro agudo aliado ao $\mathrm{V}$ mais elevado, estes dois elementos 
contrários no que concerne a qualidade tímbrica, tornaram similares os dois momentos em termos de espectro. Porém na segunda seção de B1.2, há a ocorrência de notas em $f f$, fator que aportou essa intensidade para o espectro.

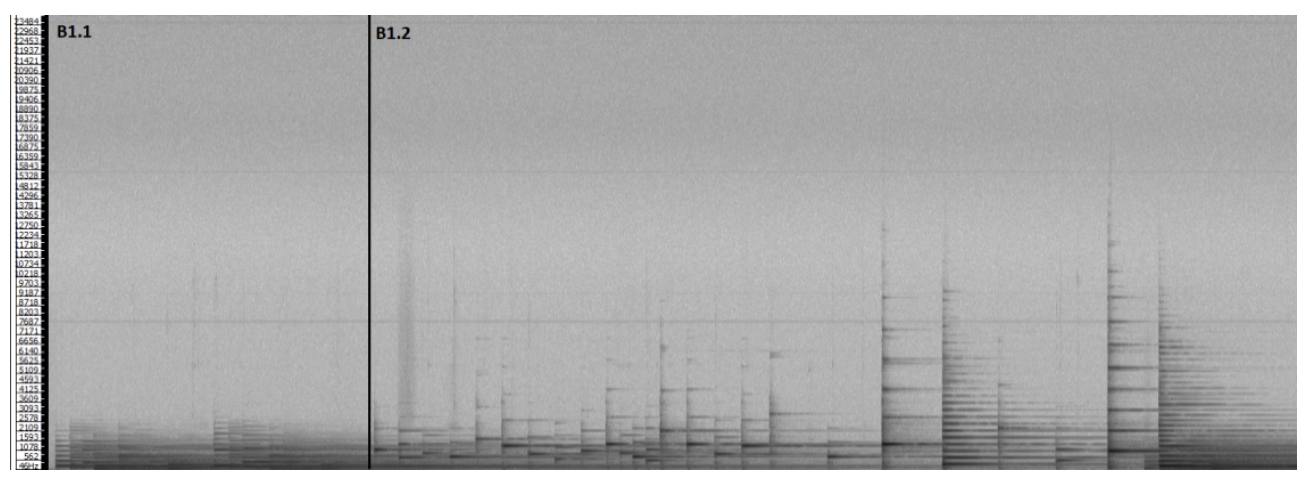

Figura 13: Espectrograma de B1

A Figura 14, com os valores de $\mathrm{CE}$, mostra similaridades com o espectrograma. B1.1 e a primeira metade de B1.2 se mostram parelhas no que concerne os valores de $\mathrm{CE}$, porém, observa-se um menor ranhuramento em B1.2, que indica o maior espaçamento temporal entre um onset e outro. É interessante observar que enquanto as semicolcheias do compasso 39 de B1.1 tiveram média de duração de $427 \mathrm{~ms}$, as colcheias de B1.2 tiveram média de $275 \mathrm{~ms}$. Essa diferença no tempo de contato com a tecla indica uma diferença de toque a partir do momento em que aparecem acentos nas notas da mão direita em B1.2 onde a velocidade de ataque mais rápida e o tempo menor de contato com a nota caracterizam a acentuação das mesmas. Já a partir da segunda metade de B1.2 os valores de $C E$ se mostram mais elevados, relevando uma maior velocidade de ataque (em decorrência das dinâmicas mais elevadas) e uma sonoridade mais brilhante. 


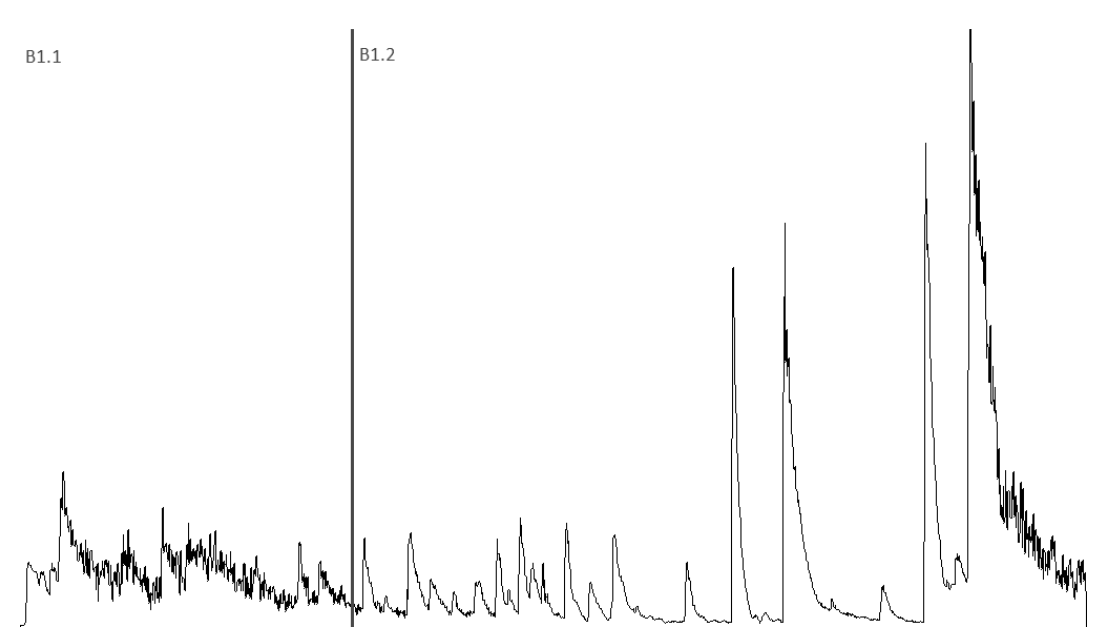

Figura 14: Centroide espectral em B1

\section{$6.8 \mathrm{~B} 2$}

A frase B2 (cc. 41-46) é um sintagma que se divide em três momentos sonoros, sendo que o momento central é contrastante enquanto os outros dois momentos são similares. B2.1 (cc.41-43) e B2.3 (c. 46) se caracterizam por uma dinâmica forte, utilização do toque legato e dos registros médio e grave. Nestes trechos optou-se por utilizar um toque com velocidade de ataque mais baixa, tendo em vista uma sonoridade mais aveludada, neutralizando os ataques individuais de cada nota, corroborando com a criação do legato. No momento sonoro central, B2.2 (cc. 44-45), o registro é alterado, passando para o agudo do piano, e também a textura muda, passando a conter notas mais rápidas (fusas) e homorritmia entre as duas mãos. Para que estas diferenças fossem ainda mais evidentes, houve a decisão de realizar um toque com velocidade de ataque mais rápida, buscando uma sonoridade brilhante e mais percussiva. Neste trecho o pedal da direita é utilizado desde o início até o fim, sem trocas. Em B2 ocorre, como em algumas frases precedentes, a intercalação de um momento sonoro contrastante com retorno ao momento sonoro inicial, em uma espécie de rememoração. 


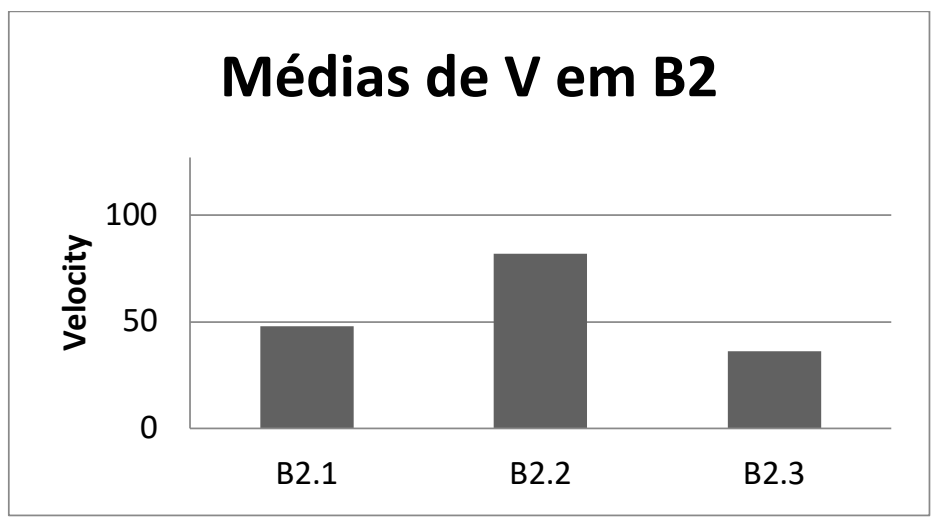

Gráfico 14: Médias de V em B2

O Gráfico14 mostra as médias de $\mathrm{V}$ nas subseções de B2, sendo estas 48 para B2.1, 82 para B2.2 e 36 para B2.3. Os valores obtidos mostram de fato a execução dos intentos interpretativos, mantendo certa consistência entre B2,1 e B2.3 e um claro contraste neste parâmetro em B2.2

Os valores de Q (Gráfico 15), por sua vez, mostram uma queda em B2.2, passando de 0,38 em B2.1 para 0,18 em B2.2 e O,34 em B2.3. Novamente o registro atuou aqui como fator preponderante na diminuição de Q em B2.2, em virtude da utilização do registro agudo do piano. Também relevante é novamente a consistência entre B2.1 e B2.3, determinando um retorno às características sonoras iniciais.

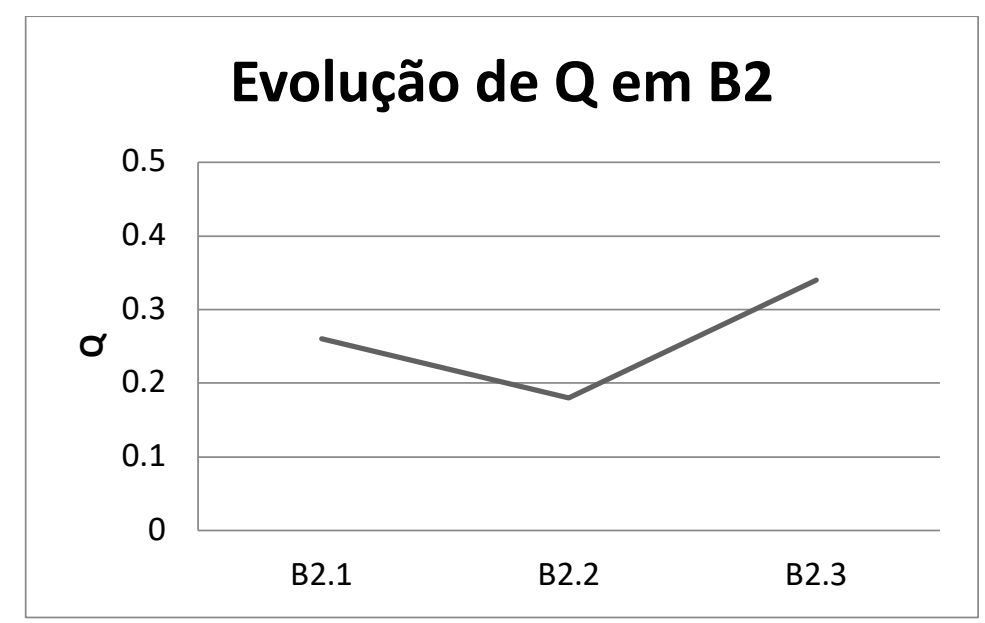

Gráfico 15: Evolução de Q em B2

O espectrograma abaixo (Figura 15) demonstra também a similaridade entre as seções B2,1 e B2.3 e o contraste no trecho central, B2.2. 


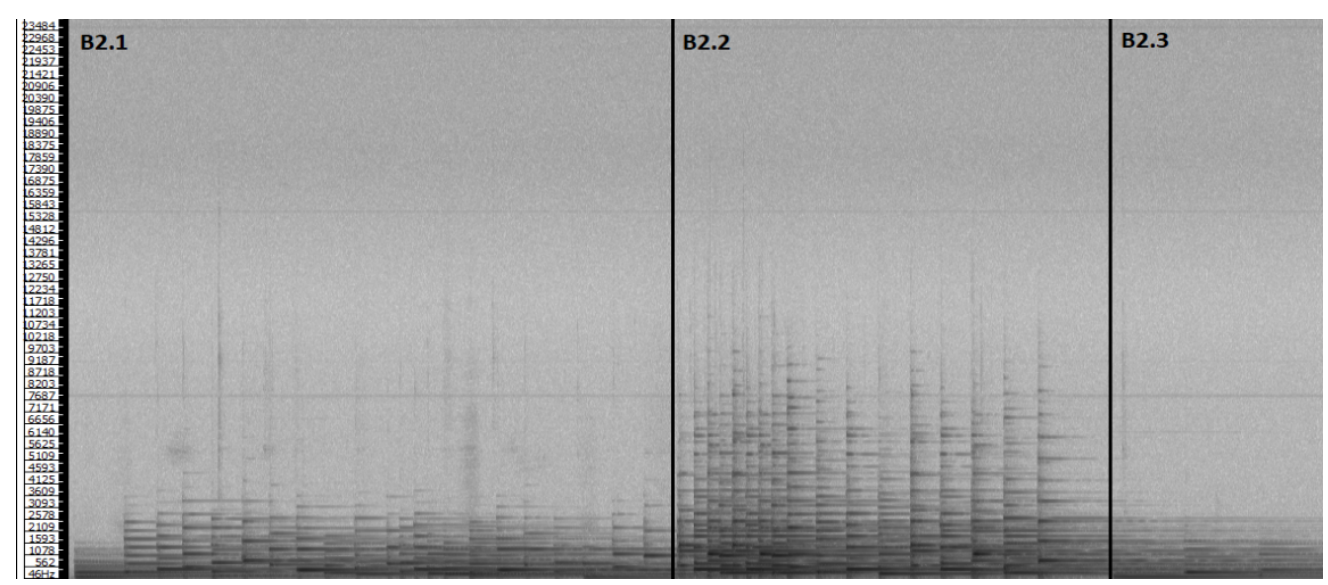

Figura 15: Espectrograma de B2

É considerável o aumento de harmônicos, em termos de quantidade e intensidade, no espectro de B2.2, o que indica um som mais rico no que concerne a presença de harmônicos. Isso indica que a velocidade de ataque elevada teve efeito direto no timbre deste momento sonoro.

A imagem que corresponde aos valores de CE (Figura 16) também indica correspondência entre B2.1 e B2.2, com valores mais baixos, e uma grande elevação dos valores em B2.2, apontando a presença de uma sonoridade mais brilhante.

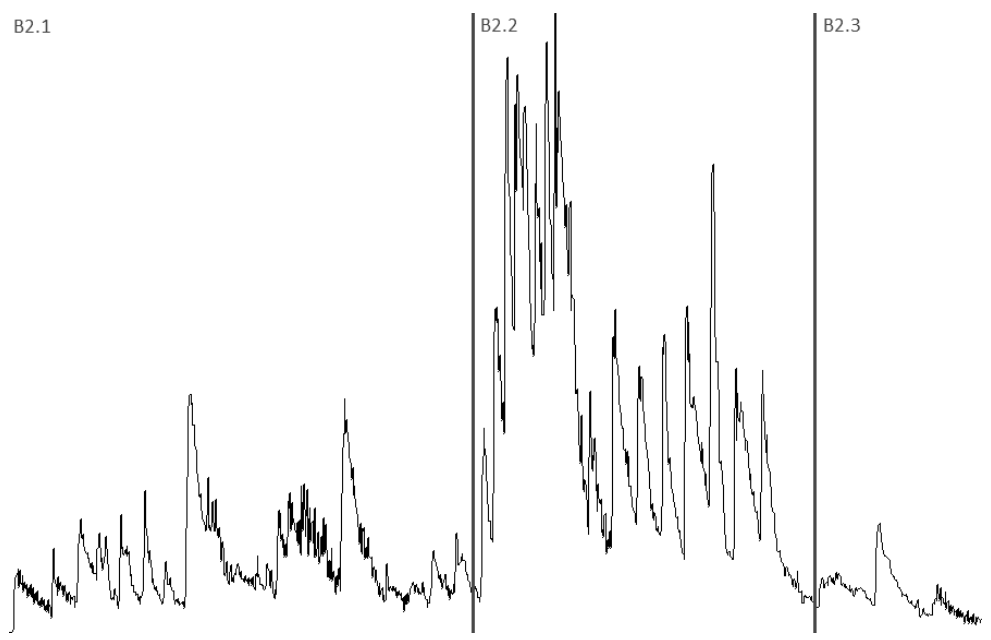

Figura 16: Centroide espectral em B2

\section{$6.9 \mathrm{~B} 3$}

A frase B3 (cc. 47-52) é um sintagma constituído por dois momentos sonoros; o primeiro deles (B3.1, cc. 47-51) se passa nos registros médio e grave do piano, com textura predominante de uma melodia na mão direita acompanhada 
por notas mais longas na mão esquerda. A dinâmica se mantém entre f e ff. No segundo momento, B3.2 (c. 52), o contraste é criado através da subida para o registro superagudo, mudança para uma textura monofônica, com ritmo mais regular e com notas mais rápidas (fusas). Com o propósito de salientar estas grandes diferenças na escrita da sonoridade, foram tomadas duas decisões interpretativas: executar B3.2 com dinâmica $p$, utilizando um toque com velocidade de ataque mais lenta, afim de evitar um som percussivo, e também inserir o pedal una corda, para auxiliar na mudança de timbre pretendida. O pedal da direita foi utilizado em B3 de maneira ininterrupta desde o início até o fim.

O Gráfico 16 das médias de $\mathrm{V}$ em B3 abaixo mostra um valor médio de $\mathrm{V}$ de 78 em B3.1 e de 35 em B3.2. Estes dados mostram uma diferenciação relevante entre um toque e outro, como pretendido na interpretação do trecho.

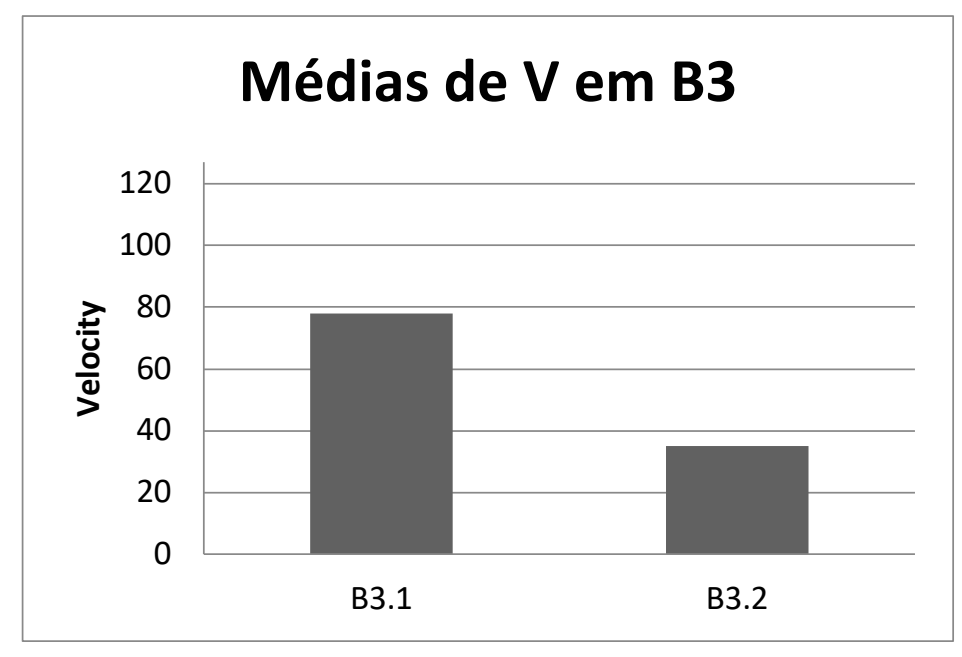

Gráfico 16: Médias de V em B3

O Gráfico 17 do valor Q, mostra um grande declínio neste parâmetro em B3.2, passando de 0,56 no primeiro momento para 0,02 no segundo. Esta grande diferenciação diz respeito à alteração em três elementos que retiram valor da qualidade tímbrica no piano: (1) a utilização dos registros mais agudos; (2) a velocidade de ataque consideravelmente mais baixa; e (3) a utilização do pedal una corda. Assim, a combinação de alterações nestes três elementos constituintes do timbre no piano, foi a causa do contraste acentuado. 


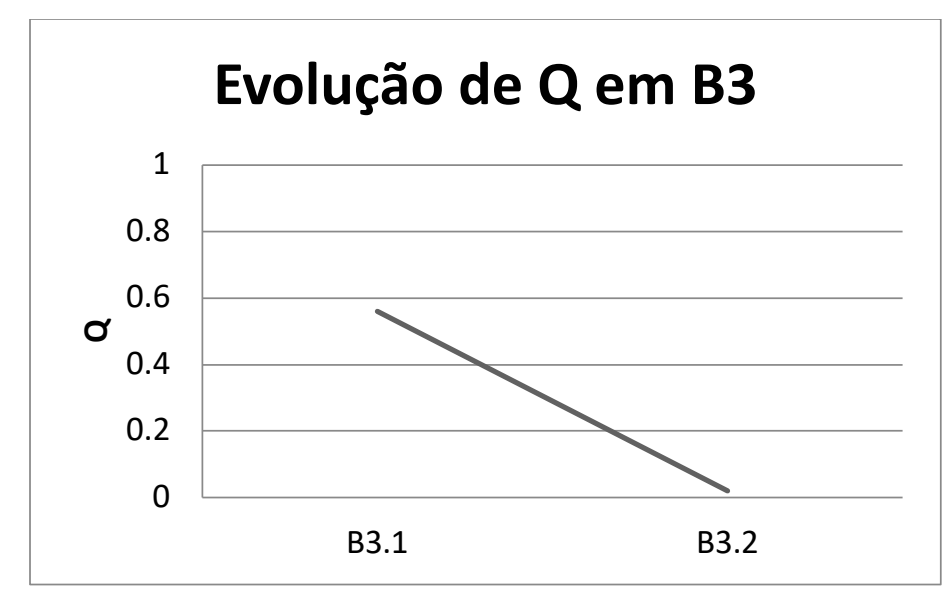

Gráfico 17: Evolução de Q em B3

Abaixo, o espectrograma (Figura 17) mostra uma sonoridade mais rica em harmônicos em B3.1 em termos de quantidade e intensidade, e uma sonoridade com espectro mais simples em B3.2, o que vem corroborar com as informações do valor $Q$.

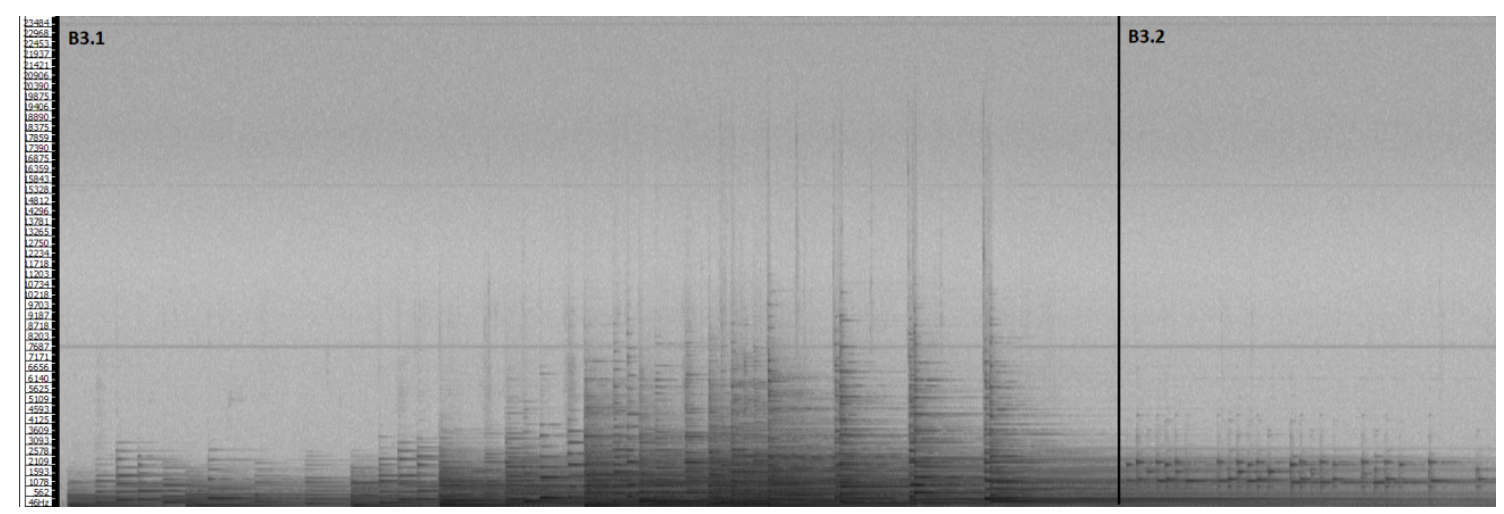

Figura 17: Espectrograma de B3

Por fim, os valores de CE se mostraram mais baixos em B3.2, que, apesar de ocorrer no registro agudo, teve sua qualidade de brilho atenuada pelos fatores interpretativos, a velocidade de toque mais baixa e o acionamento do pedal una corda (Figura 18). 


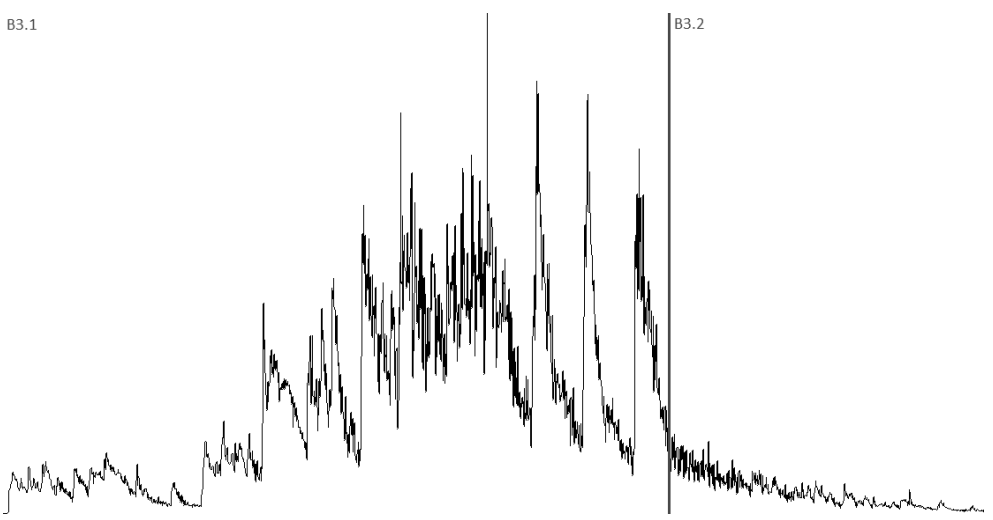

Figura 18: Centroide espectral em B3

\section{$6.10 \mathrm{~B} 4$}

A frase B4 (cc. 53-55) é um sintagma formado por dois momentos sonoros, B4.1 (c. 53) e B4.2 (cc. 54-55). O primeiro momento sonoro, B4.1 (c. 54) tem dinâmica $p$ e neste houve a opção por utilizar um toque com velocidade de ataque mais rápida e bastante legato. Já em B4.2, a dinâmica diminui para $p p$ e o registro passa a ser levemente mais agudo. Neste segundo momento houve a utilização de um toque com velocidade de ataque mais lenta e um toque non legato. Em toda a frase o pedal da direita se manteve acionado, sem trocas.

No Gráfico 18 são identificadas as médias do velocity em B4, mostrando valores de 42 para B4.1 e 34 para B4.2.

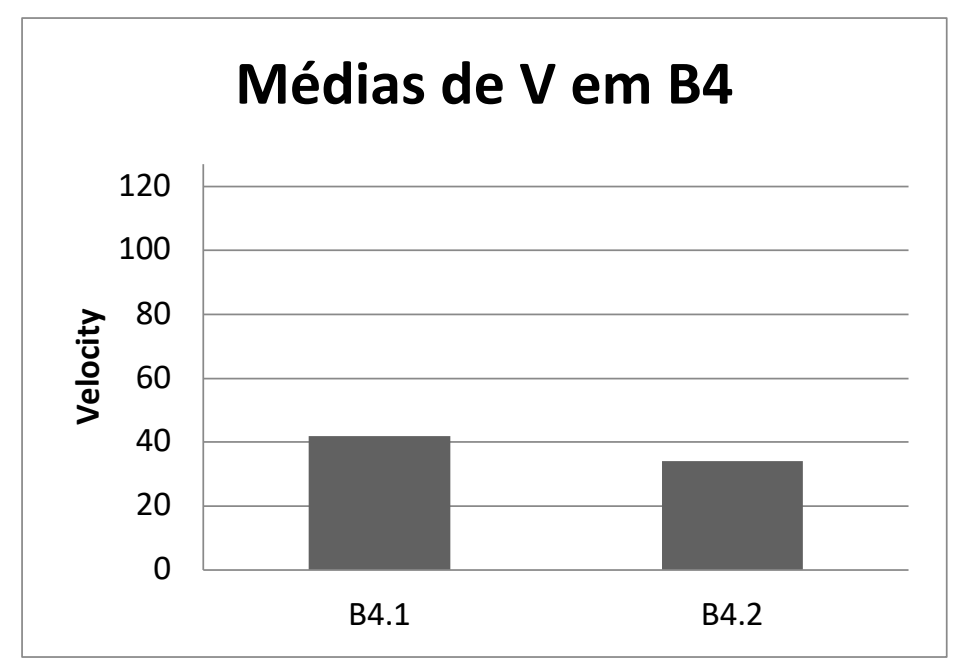

Gráfico 18: Médias de V em B4

De maneira geral, há correspondência entre perfil interpretativo pretendido e os dados expostos por este parâmetro, de modo que B4.1 demonstra V mais elevado do que B4.2 (Gráfico 19). 


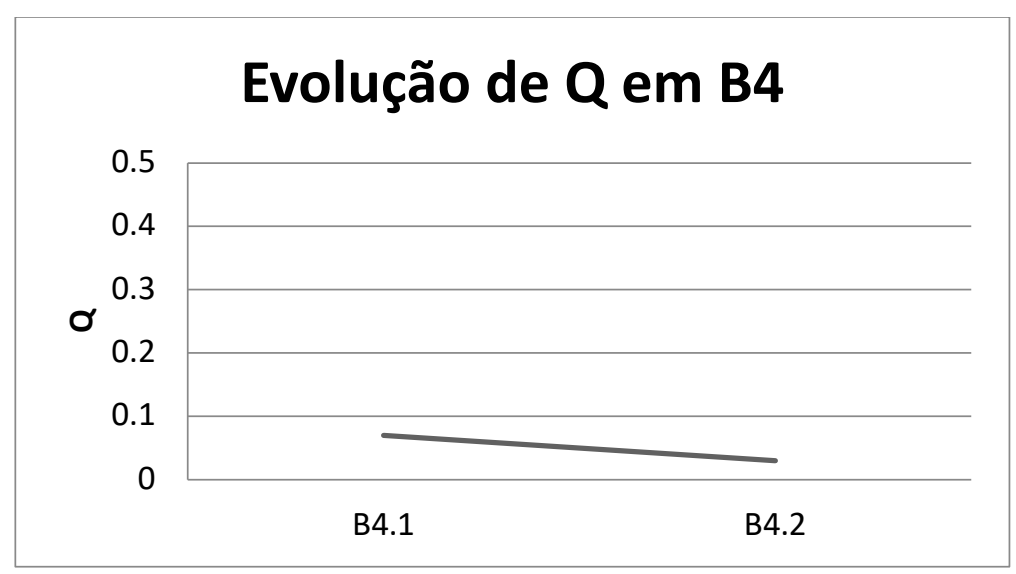

Gráfico 19: Evolução de Q em B4

Os números de Q mostram uma evolução semelhante à $\mathrm{V}$, ocorrendo uma diminuição em B4.2, que passa de 0,07 para 0,03, e que está ligada principalmente à diminuição de $\mathrm{V}$ e ao registro um pouco mais agudo.

No espectrograma (Figura 19) vê-se que em B4.1 há maior concentração e intensidade de harmônicos em comparação com B4.2. Além da mudança de $V$, a alteração entre os toques legato e non legato também contribuiu para esta diferenciação. No primeiro toque, legato, há maior tempo de permanência com a tecla abaixada, o que ocasiona uma maior ressonância, enquanto no toque non legato a tecla é mantida pressionada por menos tempo, diminuindo a ressonância. Nas apojaturas em colcheia do compasso 53, a duração média foi de $895 \mathrm{~ms}$, enquanto nas colcheias do compasso seguinte, 54, a média foi de $286 \mathrm{~ms}$. Deste modo é possível observar a utilização do tempo de manutenção da tecla pressionada como elemento constituinte da sonoridade característica de cada momento, ocasionando em um som com mais ressonância no primeiro caso e com menor ressonância no segundo.

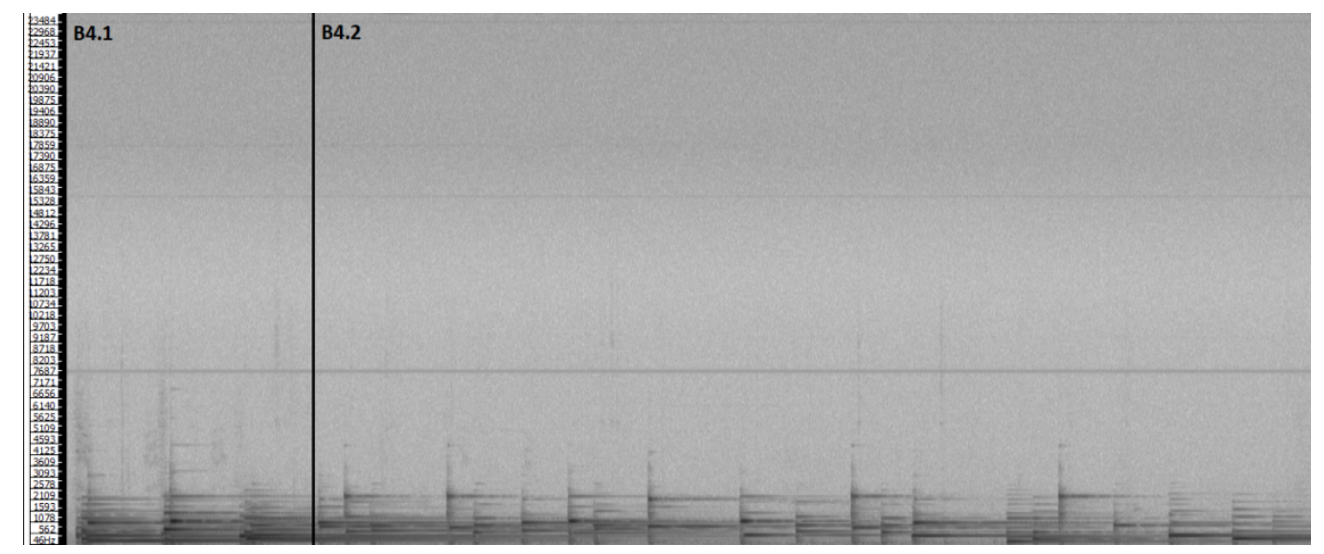

Figura 19: Espectrograma de B4 
A imagem de CE, Figura 20, remete também às decisões interpretativas, sendo que o maior valor atingido foi em B4.1, onde justamente $\mathrm{V}$ foi mais elevado, o que ocasionou a localização mais elevada do centro de massa do espectro.

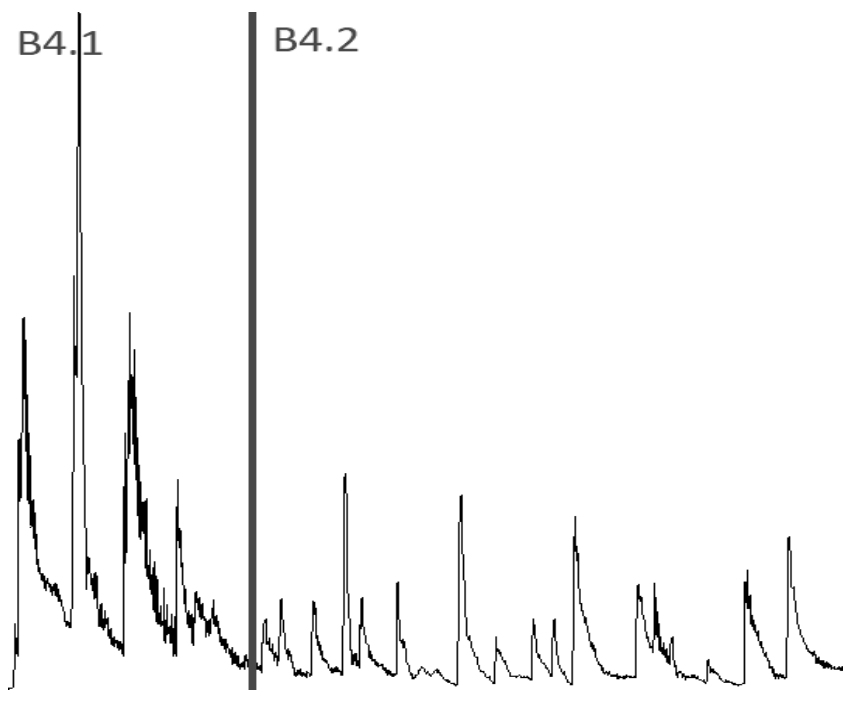

Figura 20: Centroide espectral em B4

\section{$6.11 \mathrm{~B} 5$}

A frase B5 (cc. 56-61) é um sintagma que se divide em dois momentos. Em B5.1 (cc. 56-57), o registro utilizado é o grave e a textura é a de uma linha melódica, compartilhada pelas duas mãos. Para formular um contraste com o final da frase precedente (em $m p$ ), decidiu-se realizar este trecho em dinâmica $m f$ e utilizando uma velocidade de ataque mais rápida. Em oposição, B5.2 tem uma textura mais cordal, no registro médio e agudo e utilizando a dinâmica $p p$. Neste segundo sintagma o toque utilizado teve velocidade de ataque lenta e empregouse o pedal una corda no último compasso, onde há indicação $p p p$. O pedal da direita se manteve acionado durante todo o trecho.

Observando as médias de V em B5 no Gráfico 20, verifica-se uma significativa diminuição de 50 em B5.1 para 30 em B5.2, o que confirma o intento interpretativo: 


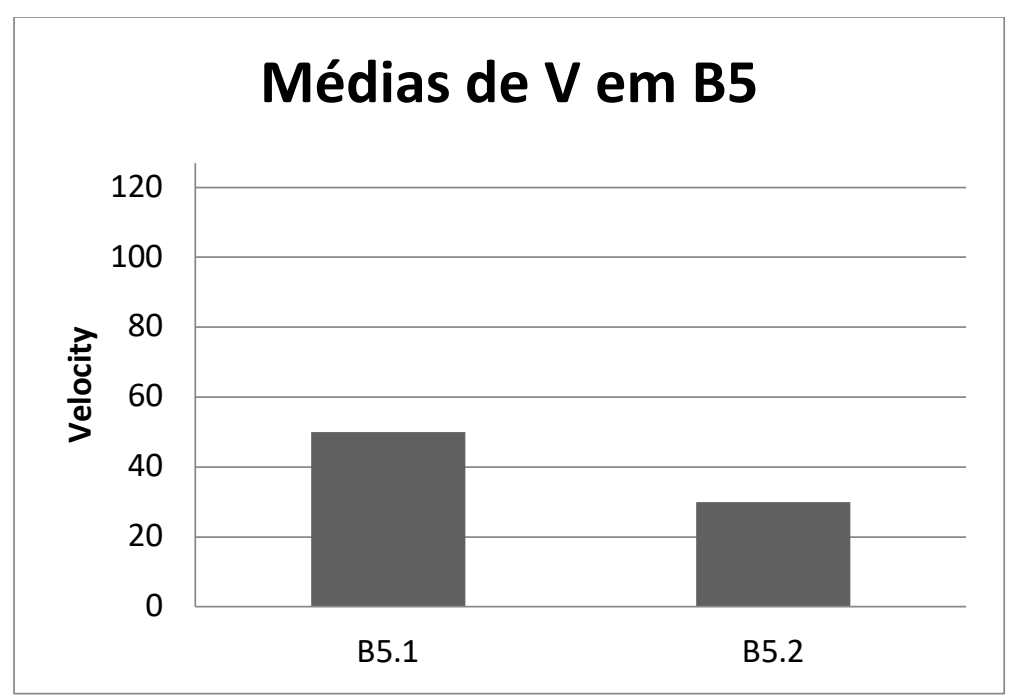

Gráfico 20: Médias de V em B5

O valor de Q ilustrado no Gráfico 21 aparece em conformidade com V, apresentando diminuição em B5.2. O decréscimo de 0,32 para 0,16 em B5.2 remete à diminuição no velocity, à utilização sobretudo do registro agudo e à inserção do pedal una corda no último compasso do trecho.

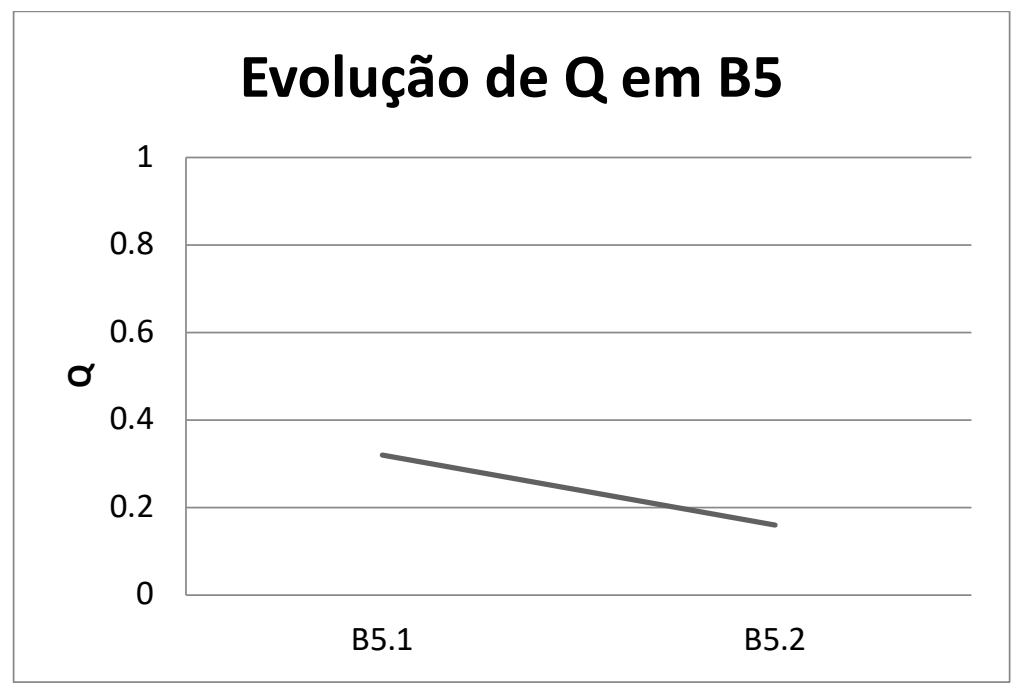

Gráfico 21: Evolução de Q em B5

No espectrograma (Figura 21), o momento onde existe maior ressonância, perceptível através da maior quantidade e intensidade dos harmônicos do espectro, é B5.1, que se relaciona com V mais elevado e com o pedal da direita acionado. A imagem referente à B5.2 mostra uma presença muito escassa e pouco perceptível de harmônicos, o que remete ao $\mathrm{V}$ baixo e ao uso do pedal una corda 
MUSICA THEORICA Revista da Associação Brasileira de Teoria e Análise Musical 2018, v. 3, n. 2, p. 1-45 - Journal of the Brazilian Society for Music Theory and Analysis@ TeMA 2018 - ISSN 2525-5541

no final do trecho, elementos que atuaram como neutralizadores da ressonância natural do piano no registro grave.

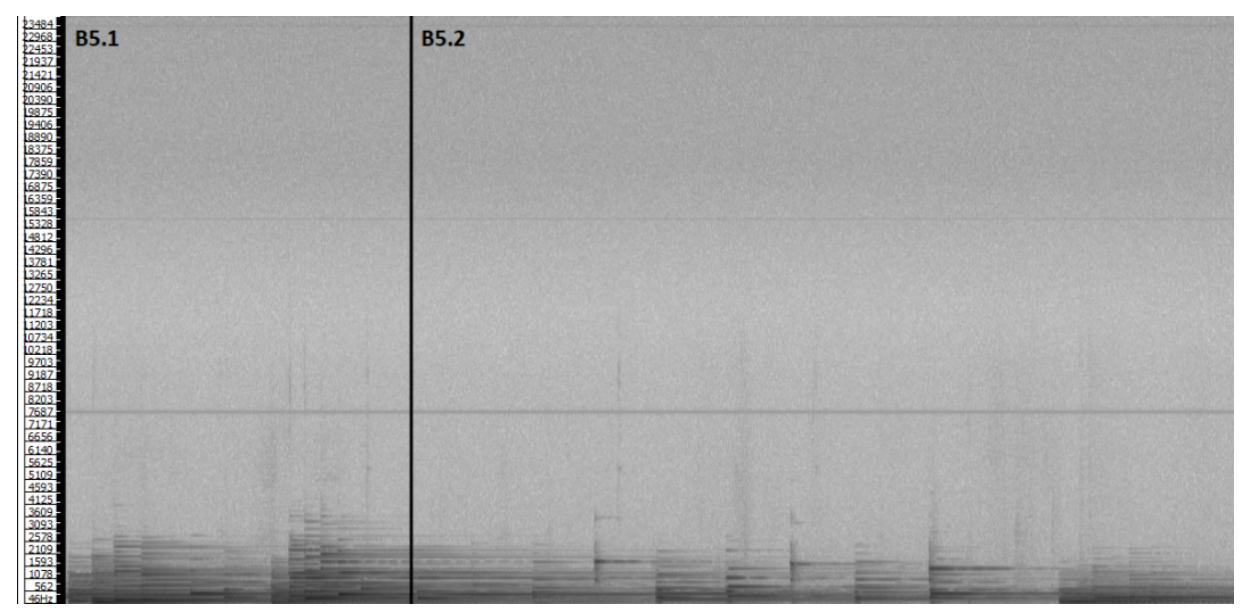

Figura 21: Espectrograma de B5

Por fim, a imagem de CE (Figura 22) mostra valores mais elevados em B5.1, onde se buscou um som mais brilhante e com maior velocidade de ataque. Por outro lado, B5.2 apresenta menor valor de CE, justamente onde pretendeuse uma sonoridade mais suave e com uso do una corda.

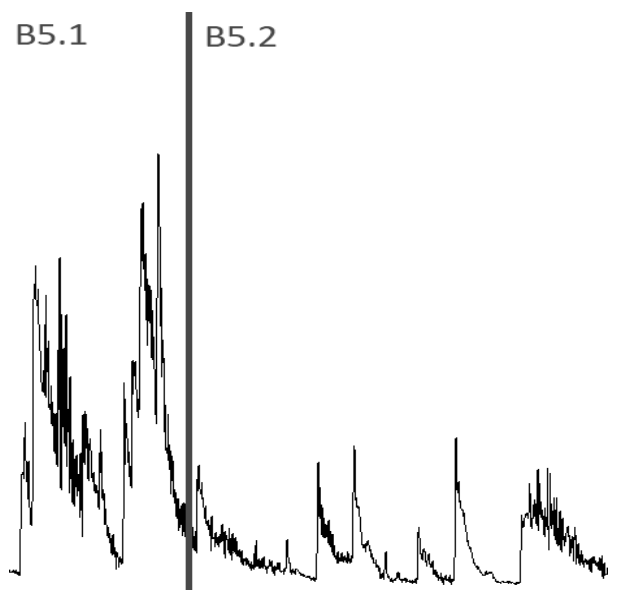

Figura 22: Centroide espectral em B5

\section{$6.12 \mathrm{~B} 6$}

A última frase desta intepretação de Contrastes, B6 (cc. 62-69), é formada por um sintagma que se divide em dois momentos sonoros que contrastam. $\mathrm{O}$ primeiro deles, B6.1 (cc. 62-65), se identifica por uma dinâmica em f e ff, a qual foi vinculada uma velocidade de ataque rápida, para que um som brilhante fosse gerado, e pelo uso do registro médio e agudo. O contraste em B6.2 (cc.66-67) 
ocorre principalmente na dinâmica, que agora ocorre em $p$, e ao uso de uma velocidade de ataque mais lenta, neste caso visando uma sonoridade mais opaca (e oposta àquela de B6.1). Em B6 inteira o pedal da direita é acionado e não ocorrem trocas de pedal. Porém, ao fim de B6.2 há a utilização do pedal una corda. A ideia interpretativa para esta frase final foi de criar uma espécie de "decrescendo" de timbres, indo do mais brilhante para o mais opaco.

No Gráfico 22, as médias de V em B6 indicam um decréscimo, indo de 76 em B6.1 para 32 em B5.2. A grande diminuição entre a primeira e a segunda subseção mostra a mudança no toque pianístico.

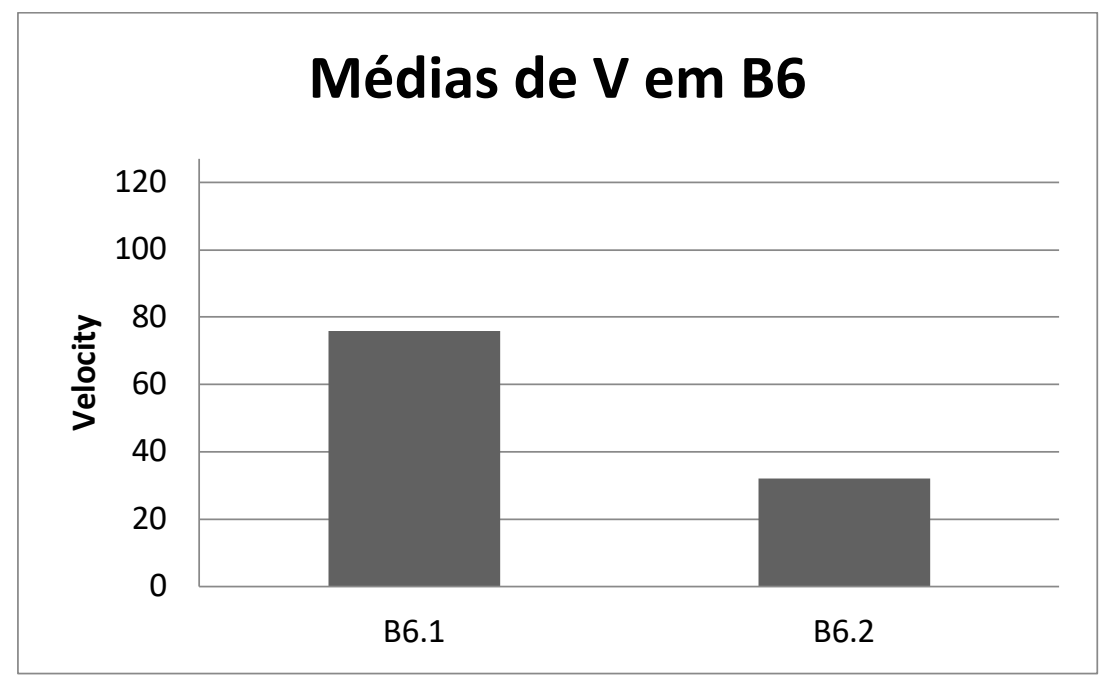

Gráfico 22: Médias de V em B6

O gráfico que ilustra os valores médios de $\mathrm{Q}$ nesta última frase apresenta um grande declínio de B5.1 para B5.2, passando de 0,32 para 0,08. Esta queda engloba três elementos; o registo levemente mais agudo, a velocidade de ataque bastante mais lenta e a utilização do pedal una corda no último compasso de B5.2. 
MUSICA THEORICA Revista da Associação Brasileira de Teoria e Análise Musical 2018, v. 3, n. 2, p. 1-45 - Journal of the Brazilian Society for Music Theory and Analysis@ TeMA 2018 - ISSN 2525-5541

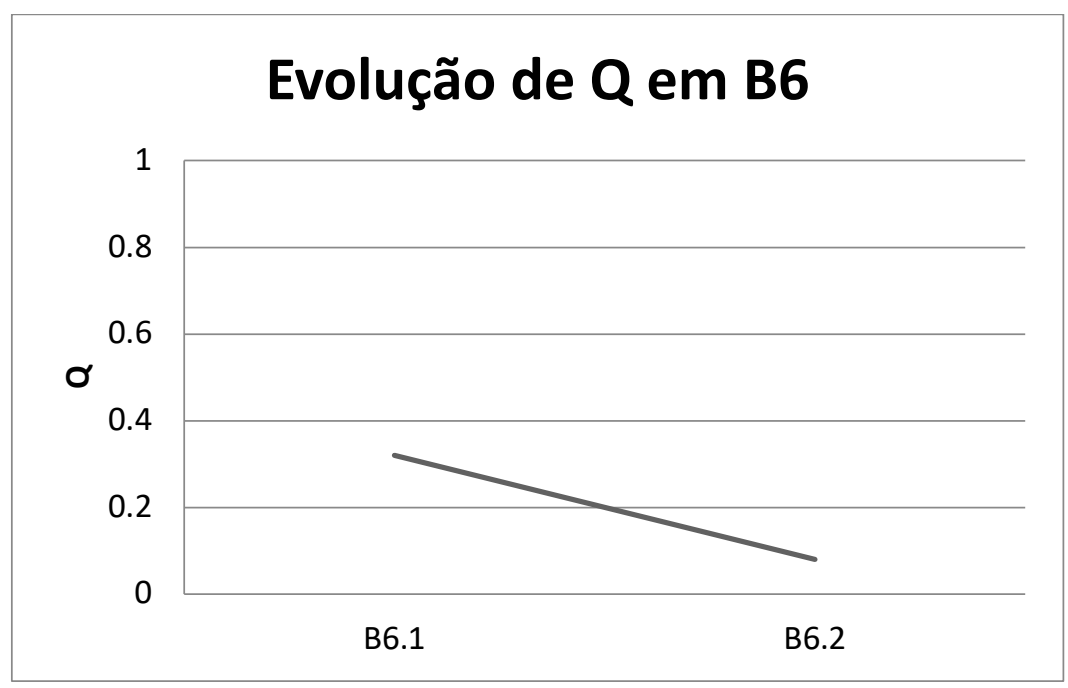

Gráfico 23: Evolução de Q em B6

No espectrograma (Figura 23) a progressiva diminuição de intensidade e quantidade de harmônicos presentes no espectro é evidente, principalmente entre B6.1 e B6.2. Tal diminuição reflete o acionamento progressivo de elementos que retiram ressonância do timbre do piano.

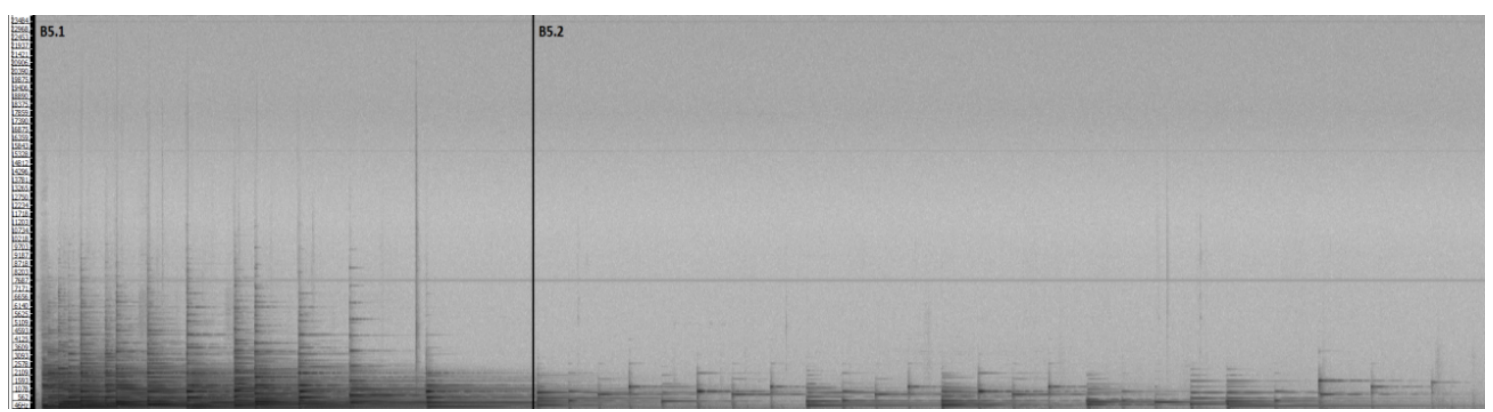

Figura 23: Espectrograma de B6

O CE corrobora com as informações trazidas pelos outros parâmetros analisados, indicando uma sonoridade onde o centro de massa do espectro se localiza nas frequências mais agudas em B6.1, e um grande decréscimo em B6.2. Aqui é verificável a passagem de uma sonoridade com mais brilho no início da frase para uma mais opaca na finalização da mesma (Figura 24). 


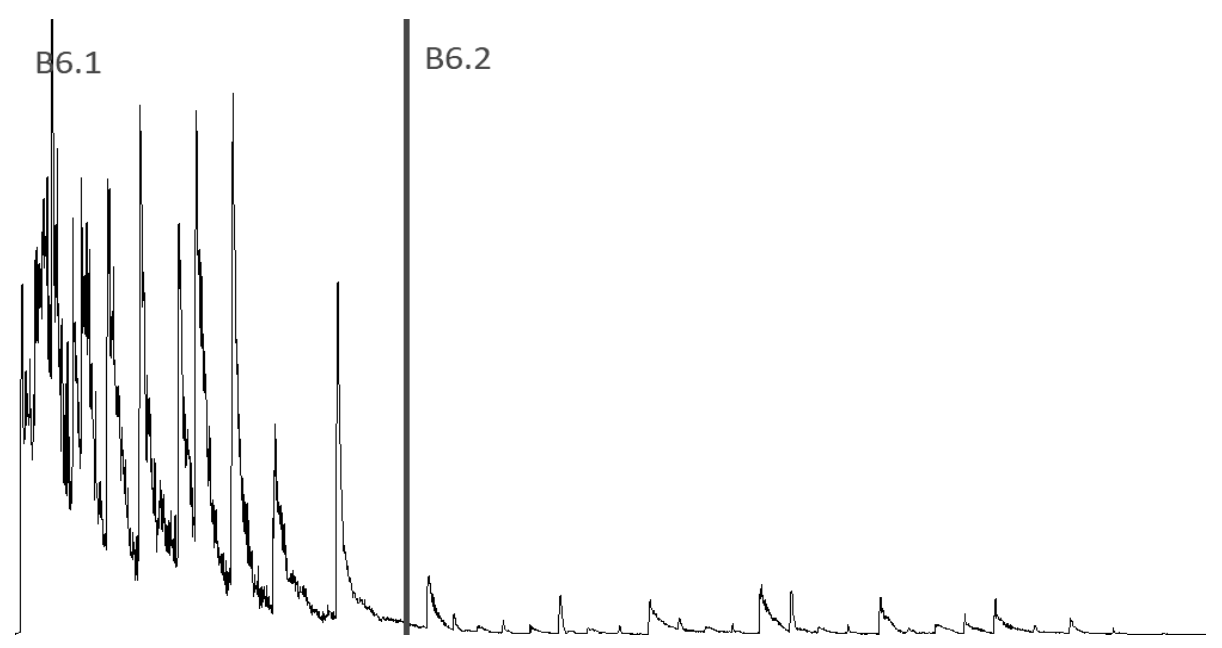

Figura 24: Centroide espectral em B6

\section{A forma da sonoridade}

Neste último tópico da análise da sonoridade de Contrastes de Marisa Rezende, serão expostos alguns dados do comportamento da sonoridade na peça como um todo. Inicialmente, o Gráfico 24 abaixo mostra a evolução da qualidade sônica básica $(Q)$ em cada uma das unidades sonoras da peça:

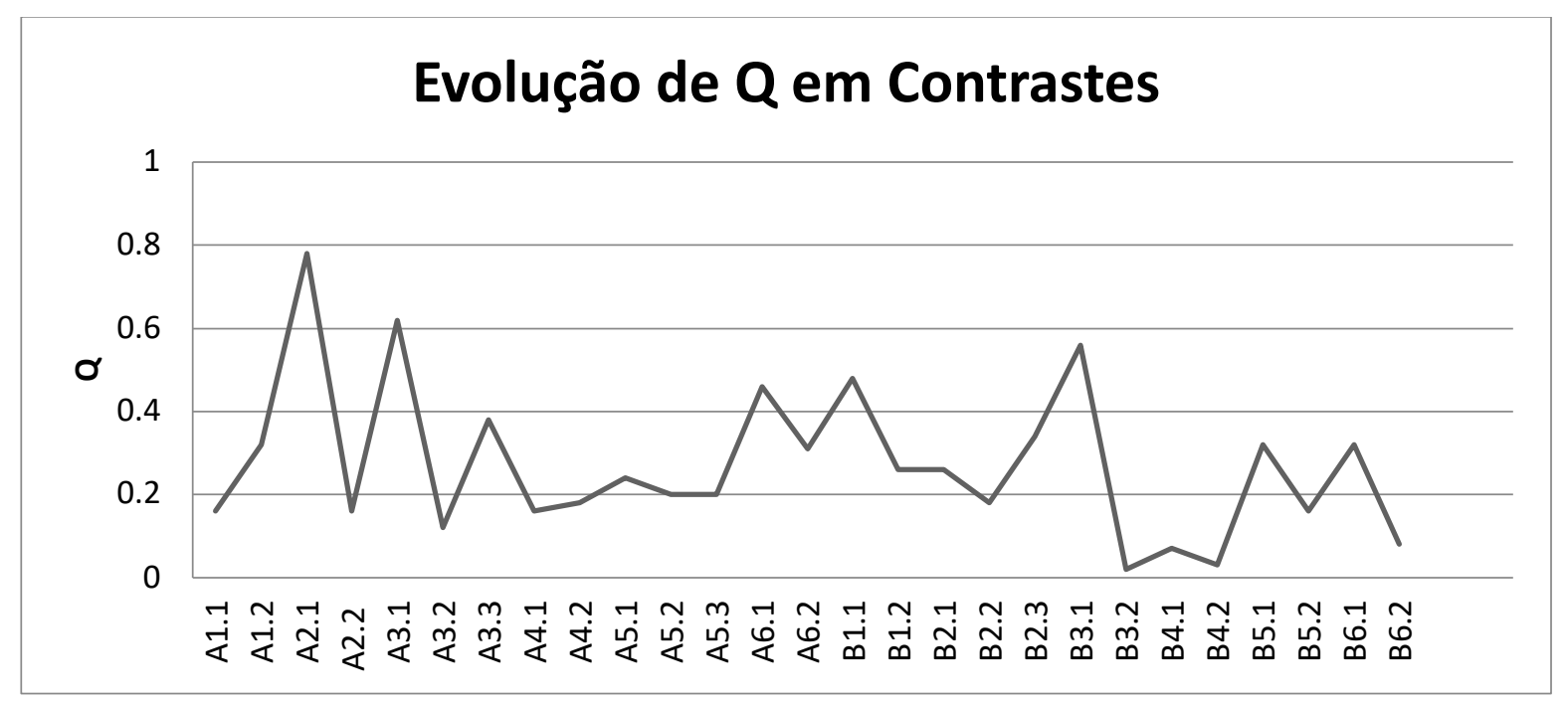

Gráfico 24: Evolução de Q em Contrastes

É interessante reparar na configuração quase sempre triangular da linha gerada, que sobe e desce de unidade para unidade. Essa diferenciação mostra de modo claro a criação de contrastes sonoros durante a peça toda, em maior ou menor grau, já que o cálculo de Q leva em consideração o velocity, o registro e o uso dos pedais, que foram os elementos centrais das análises realizadas. Também 
MUSICA THEORICA Revista da Associação Brasileira de Teoria e Análise Musical 2018, v. 3, n. 2, p. 1-45 - Journal of the Brazilian Society for Music Theory and Analysis@ TeMA 2018 - ISSN 2525-5541

é oportuno verificar que o valor de $Q$ entre os sintagmas (de A1.2 para A2.1, A2.2 para A3.1, etc.) também sofre alteração, o que revela o contraste entre as frases, além do contraste interno de suas unidades sonoras geradoras.

As imagens trazidas com os dados gerados do espectrograma e dos valores do centroide espectral também facilitam a visualização dos contrastes internos e entre frases na peça, de modo que cada barra delimita um trecho com características sonoras e contrastes próprios.

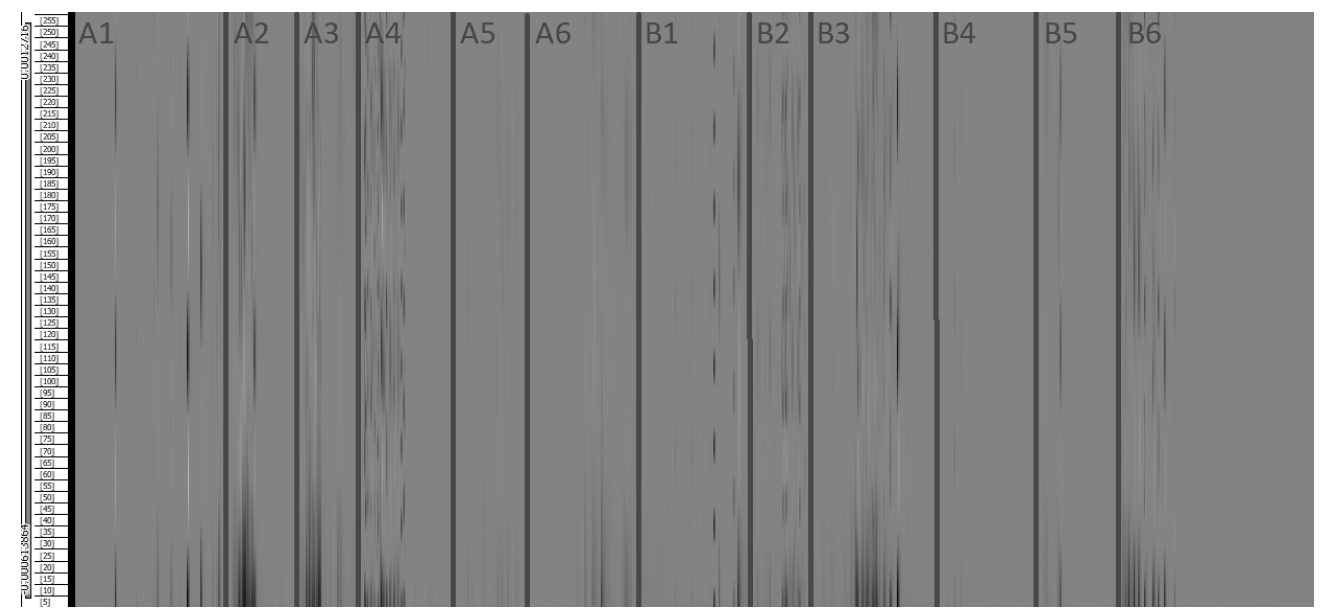

Figura 25: Espectrograma de Contrastes

No espectrograma (Figura 25) se vê a intercalação de momentos com mais intensidade e quantidade de harmônicos com momentos de menor intensidade e quantidade dos mesmos. Na imagem de CE (Figura 26), por sua vez, além da intercalação entre momentos com picos mais elevados (onde houve a preponderância de um som mais brilhante) e momentos com picos menores (onde o som adquiriru características mais opacas), pode-se observar os picos mais ranhurados e os mais espaçados, indicando respectivamente um menor ou maior espaçamento entre onsets.

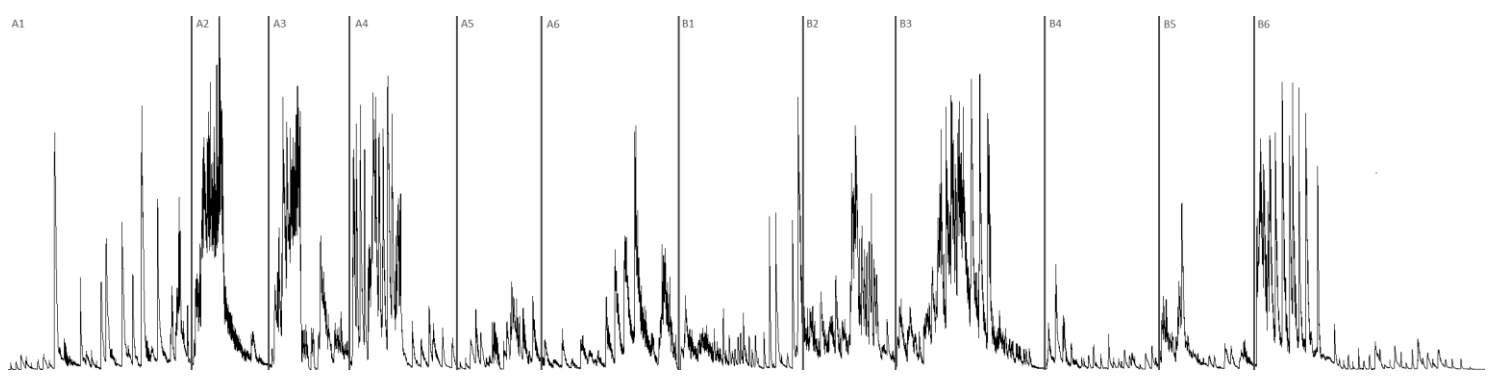

Figura 26: Centroide espectral em Contrastes 
A visualização geral da sonoridade em Contrastes permitiu a criação de uma imagem dos contrastes sonoros na peça, onde decisões interpretativas e prescrições da partitura atuaram lado a lado na construção da figura final.

\section{Considerações finais}

Esta análise da sonoridade da peça Contrastes (2001) de Marisa Rezende, se propôs a aplicar uma metodologia analítica onde as prescrições da partitura e as interferências do performer, através de suas decisões interpretativas e abordagem do instrumento, colaborassem lado a lado na identificação dos elementos sonoros centrais da peça. Para que este intuito se desse, aliamos a metodologia de análise da sonoridade de Guigue (2011) aos pressupostos da Pesquisa Artística (Coessens et al 2009) e o entendimento morfológico da obra musical (Costa 2016), a fim de permitir que houvesse margem para a inclusão do conhecimento advindo da performance e do contato experiencial com a peça na análise, além de motivar um maior envolvimento do performer no processo analítico.

Os resultados apresentados mostram um panorama geral de elementos centrais da sonoridade na peça em conexão com sua constituição formal e fraseológica. Apesar de entrar no escopo de uma performance em específico (a da pianista e primeira autora deste artigo), os pressupostos gerais em relação à sonoridade são universais: por mais que se mude o intérprete e haja variações nas decisões interpretativas e abordagem do instrumento, a manipulação da sonoridade se mantém sendo o foco da obra.

O procedimento metodológico apresentado serve como um canal de abertura para a inserção da performance na análise musical, onde o texto musical e a performance atuam lado a lado na criação de significado e para a existência da peça em si. Sem o texto a performance desta peça não poderia existir e, no caminho contrário, sem a performance, não haveria a peça enquanto acontecimento real e tampouco haveria sonoridade a ser analisada. Assim, a colaboração entre compositora e intérprete se mostra como um fator manifestado de maneira não intencional e inerente à existência da obra musical.

Por fim, as análises trouxeram à tona o papel relevante do performer dentro do processo analítico, capaz de acrescentar informações relevantes sobre a obra, informações estas que somente são adquiríveis e passíveis de reconhecimento através do contato experiencial com a peça. Assim, a relevância 
MUSICA THEORICA Revista da Associação Brasileira de Teoria e Análise Musical 2018, v. 3, n. 2, p. 1-45 - Journal of the Brazilian Society for Music Theory and Analysis @ TeMA 2018 - ISSN 2525-5541

da voz do performer na produção de conhecimento em música se faz reconhecida e manifesta.

\section{Referências}

1. Caron, Jean-pierre Cardoso. 2011. Da ontologia à morfologia: Reflexões sobre a identidade da obra musical. 2011. 98 f. Dissertação (Mestrado) - Instituto de Filosofia e Ciências Sociais, Programa de Pós-graduação em Filosofia, Universidade Federal do Rio de Janeiro, Rio de Janeiro.

2. Coessens, Kathleen; Crispin, Darla; e Douglas, Anne. 2009. The artistic turn: a manifesto. Ghent, Leuven University Press.

3. Costa, Valério Fiel da. 2016. Morfologia da obra aberta. Curitiba, Prismas.

4. Guigue, Didier. 2016. Soal 4.0, Sonic Object Analysis Library: OpenMusic Tools for analyzing musical objects structure. Disponível em: https://www.academia.edu/29796175/. Acesso em 13 de junho de 2017.

5. Guigue, Didier. 2011. Estética da sonoridade: a herança de Debussy na música para piano do século XX. São Paulo: Perspectiva; CNPQ: Brasília; João Pessoa: UFPB.

6. Guigue, Didier; Noda, Luciana; e Bragagnolo, Bibiana. 2014. Timbre e Escrita ao Piano: por uma Incorporação do Comportamento Acústico do Piano na Composição e Análise Musical. Música Hodie, v. 14, n. 1, p. 137 158.

7. Rezende, Marisa. 2001. Contrastes. Rio de Janeiro: Rioarte. 1 partitura (5 páginas). Instrumento: piano solo.

8. Rezende, Marisa. 2012. Encarte de CD. In: Holanda, J. Joana Holanda - Piano Presente. Realização: Selo SESC. Produção: FRBH e Joana Holanda, Pelotas, 1 CD. (Duração: aproximadamente $56 \mathrm{~min}$ ).

9. Loureiro, Maurício; Magalhães, Tairone; Borges, Rodrigo; Campolina, Thiago; Mota, Davi; e Paula, Hugo de. 2008. Segmentação e extração de descritores de expressividade em sinais musicais monofônicos. In: III Seminário Música Ciência e Tecnologia. São Paulo. Anais do III Seminário Música Ciência e Tecnologia. São Paulo: pp. 109-125. 